\title{
26. METAMORPHISM OF ULTRAMAFIC CLASTS FROM CONICAL SEAMOUNT: SITES 778, 779, AND 780 1
}

\author{
Kristine L. Saboda, ${ }^{2}$ Patricia Fryer, ${ }^{2}$ and Hirokazu Maekawa ${ }^{3}$
}

\section{INTRODUCTION}

The Mariana arc-trench system, the easternmost of a series of backarc basins and intervening remnant arcs that form the eastern edge of the Philippine Sea Plate (Fig. 1), is a well-known example of an intraoceanic convergence zone. Its evolution has been studied by numerous investigators over nearly two decades (e.g., Karig, 1971; Uyeda and Kanamori, 1979; LaTraille and Hussong, 1980; Fryer and Hussong, 1981; Mrosowski et al., 1982; Hussong and Uyeda, 1981; Bloomer and Hawkins, 1983; Karig and Ranken, 1983; McCabe and Uyeda, 1983; Hsui and Youngquist, 1985; Fryer and Fryer, 1987; Johnson and Fryer, 1988; Johnson and Fryer, 1989; Johnson et al., 1991). The Mariana forearc has undergone extensive vertical uplift and subsidence in response to seamount collision, to tensional and rotational fracturing associated with adjustments to plate subduction, and to changes in the configuration of the arc (Hussong and Uyeda, 1981; Fryer et al., 1985). Serpentine seamounts, up to $2500 \mathrm{~m}$ high and $30 \mathrm{~km}$ in diameter, occur in a broad zone along the outer-arc high (Fryer et al., 1985; Fryer and Fryer, 1987). These seamounts may be horsts of serpentinized ultramafic rocks or may have been formed by the extrusion of serpentine muds. Conical Seamount, one of these serpentine seamounts, is located within this broad zone of forearc seamounts, about $80 \mathrm{~km}$ from the trench axis, at about $19^{\circ} 30^{\prime} \mathrm{N}$ (Fig. 2). The seamount is approximately $20 \mathrm{~km}$ in diameter and rises 1500 $\mathrm{m}$ above the surrounding seafloor. Alvin submersible, $R V$ Sonne bottom photography, seismic reflection, and SeaMARC II studies indicate that the surface of this seamount is composed of unconsolidated serpentine muds that contain clasts of serpentinized ultramafic and metamorphosed mafic rocks, and authigenic carbonate and silicate minerals (Saboda et al., 1987; Haggerty, 1987; Fryer et al., 1990; Saboda, 1991).

During Leg 125, three sites were drilled (two flank sites and one summit site) on Conical Seamount to investigate the origin and evolution of the seamount.

Site $778\left(19^{\circ} 29.93^{\prime} \mathrm{N}, 146^{\circ} 39.94^{\prime} \mathrm{E}\right)$ is located in the midflank region of the southern quadrant of Conical Seamount at a depth of 3913.7 meters below sea level (mbsl) (Fig. 2). This site is located in the center of a major region of serpentine flows (Fryer et al., 1985, $1990)$. Site $779\left(19^{\circ} 30.75^{\prime} \mathrm{N}, 146^{\circ} 41.75^{\prime} \mathrm{E}\right)$, about $3.5 \mathrm{~km}$ northeast of Site 778 , is located approximately in the midflank region of the southeast quadrant of Conical Seamount, at a depth of $3947.2 \mathrm{mbsl}$ (Fig. 2). This area is mantled by a pelagic sediment cover, overlying exposures of unconsolidated serpentine muds that contain serpentinized clasts of mafic and ultramafic rocks (Fryer et al., 1985, 1990). Site 780 (19³2.5’ N, $146^{\circ} 39.2^{\prime} \mathrm{E}$ ) is located on the western side of Conical Seamount near the summit, at a depth of $3083.4 \mathrm{mbsl}$ (Fig. 2). This area is only partly sediment covered and lies near active venting fields where chimney structures are forming (Fryer et al., 1990).

\footnotetext{
'Fryer, P., Pearce, J. A., Stokking, L. B., et al., 1992. Proc. ODP Sci. Results, 125: College Station, TX (Ocean Drilling Program).

${ }^{2}$ Planetary Geosciences Division, Department of Geology and Geophysics, School of Ocean and Earth Science and Technology, University of Hawaii, 2525 Correa Road, Honolulu, HI 96822 , U.S.A.

${ }^{3}$ Department of Earth Sciences, Faculty of Science, Kobe University, Nada, Kobe, 657 , Japan.
}

The ultramafic rock types present in the seamount are primarily harzburgite with subordinant dunite that show evidence of melt extraction in an island arc environment (Fryer, Pearce, Stokking, et al., 1990; Parkinson et al., this volume; Ishii et al., this volume). The purpose of this paper is to describe the mineralogic relationships observed in the ultramafic clasts and to present an interpretation of the metamorphic history of the rocks.

\section{Petrography of Ultramafic Clasts}

In hand specimen, the serpentinized, tectonized harzburgites range in color from a deep blackish-green to a light gray. Many exhibit small-scale color variations caused by veining of serpentine and carbonate. Although most clasts are massive, some show small-scale foliation caused by alignment of bastitic orthopyroxene. The primary minerals have been altered pervasively to serpentine. The texture of the serpentine phases and their interrelationships throughout clasts recovered in all of the drillholes on this seamount fall within the range observed in the dredge and Alvin samples (Saboda, 1991). Thus, the suite of clasts recovered attests to a general uniformity in very lowto medium-grade metamorphism. Original olivine, orthopyroxene, clinopyroxene, and apparently fresh chrome-spinel are still preserved (Table 1). Serpentinized olivine (about 75-95 modal \% of the rock) forms a massive mesh-textured fabric and has no obvious crystal outlines. Bastitic orthopyroxene (5-25 modal \%) is typically kinkbanded and sometimes elongate, probably as the result of metamorphically induced stress. Clinopyroxene (1-3 modal \%) occurs as exsolution lamellae along the (100) plane of orthopyroxene and usually displays undulose extinction. Relict clinopyroxene (less than $1 \mathrm{~mm}$ in size) is also present in the margins of some orthopyroxene crystals (Girardeau and Lagabrielle, this volume). Chromium-spinel (less than $1 \mathrm{~mm}$ in size) occurs as disseminated and isolated anhedral grains. Chromium-spinels also sometimes occur as dumbbell-shaped crystals and occasionally form stringers (Girardeau and Lagabrielle, this volume).

The degree of serpentinization varies from $40 \%$ to $100 \%$. In the strongly serpentinized rocks, all of the original chromium-spinel (translucent in shades of deep reddish-brown/green when fresh) has been replaced by an opaque oxide mineral, probably magnetite. In some samples, this transformation process is incomplete. These partially altered spinels have original chromium-rich translucent cores, rims of magnetite, and radially arranged halos of microcrystalline chlorite (probably penninite). This type of alteration also has penetrated cracks in the original spinel grains.

There are numerous veins of serpentine (up to about $40 \mathrm{~mm}$ wide) cutting the harzburgites, many of which record a multistage history of filling. The degree of serpentinization of the harzburgite is usually greater near the veins. The veins contain chrysotile, and antigorite or lizardite is present in most. Some veins contain chrysotile that has grown both parallel to the original fracture walls and as discontinuous, crosscutting subsets. Subordinant brucite also is present. Some spinel trains were dislocated during the formation of serpentine veins. Orthopyroxene grains, adjacent to the veins in some samples, have been altered to chlorite. Typically, serpentinization affects olivine the most, orthopyroxene less, and clinopyroxene the least; however, in 


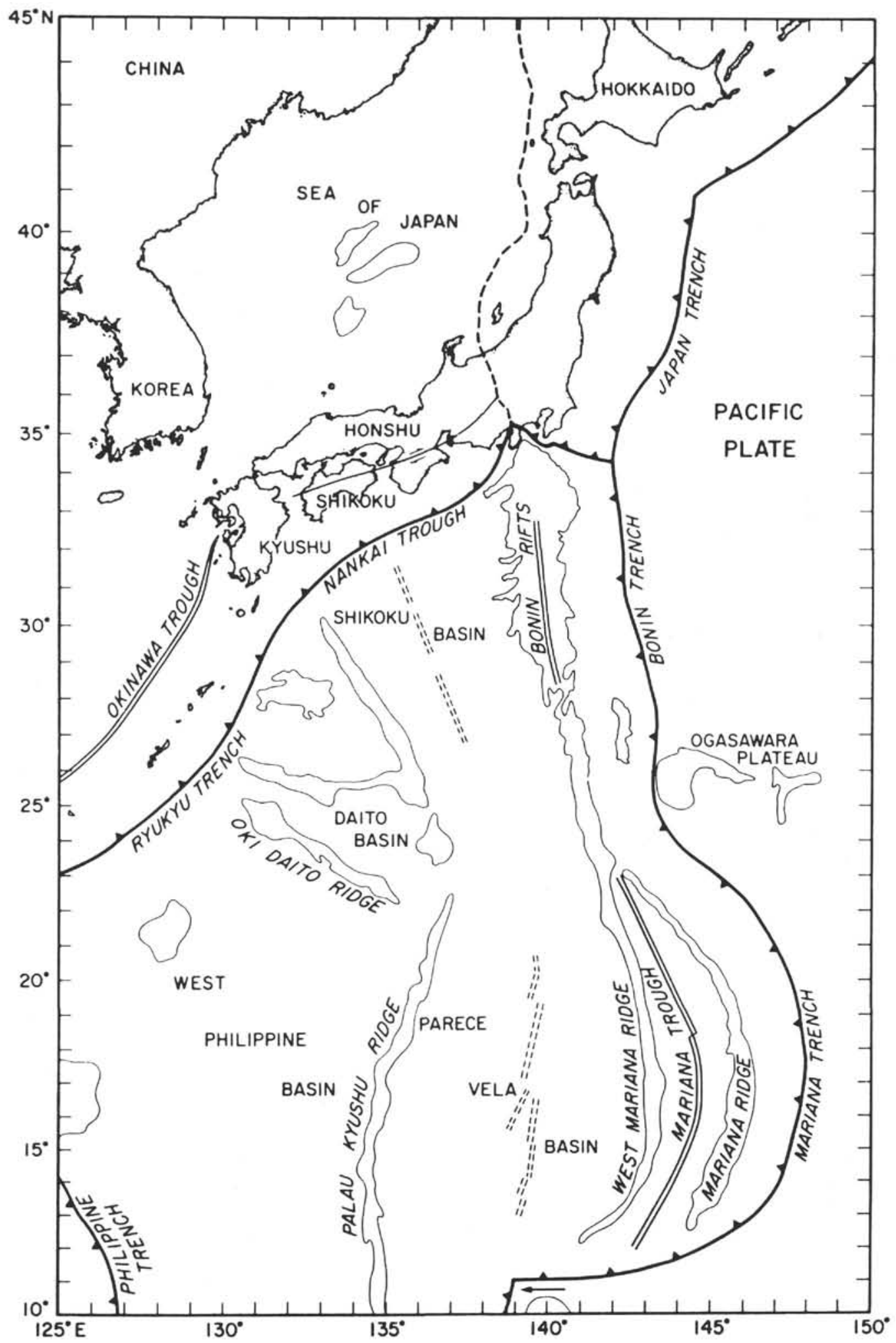

Figure 1. Location map showing the regional setting of the Mariana arc system. Solid square depicts Leg 125 drilling area. 
A

$146^{\circ} 40^{\prime} \mathrm{E}$

।

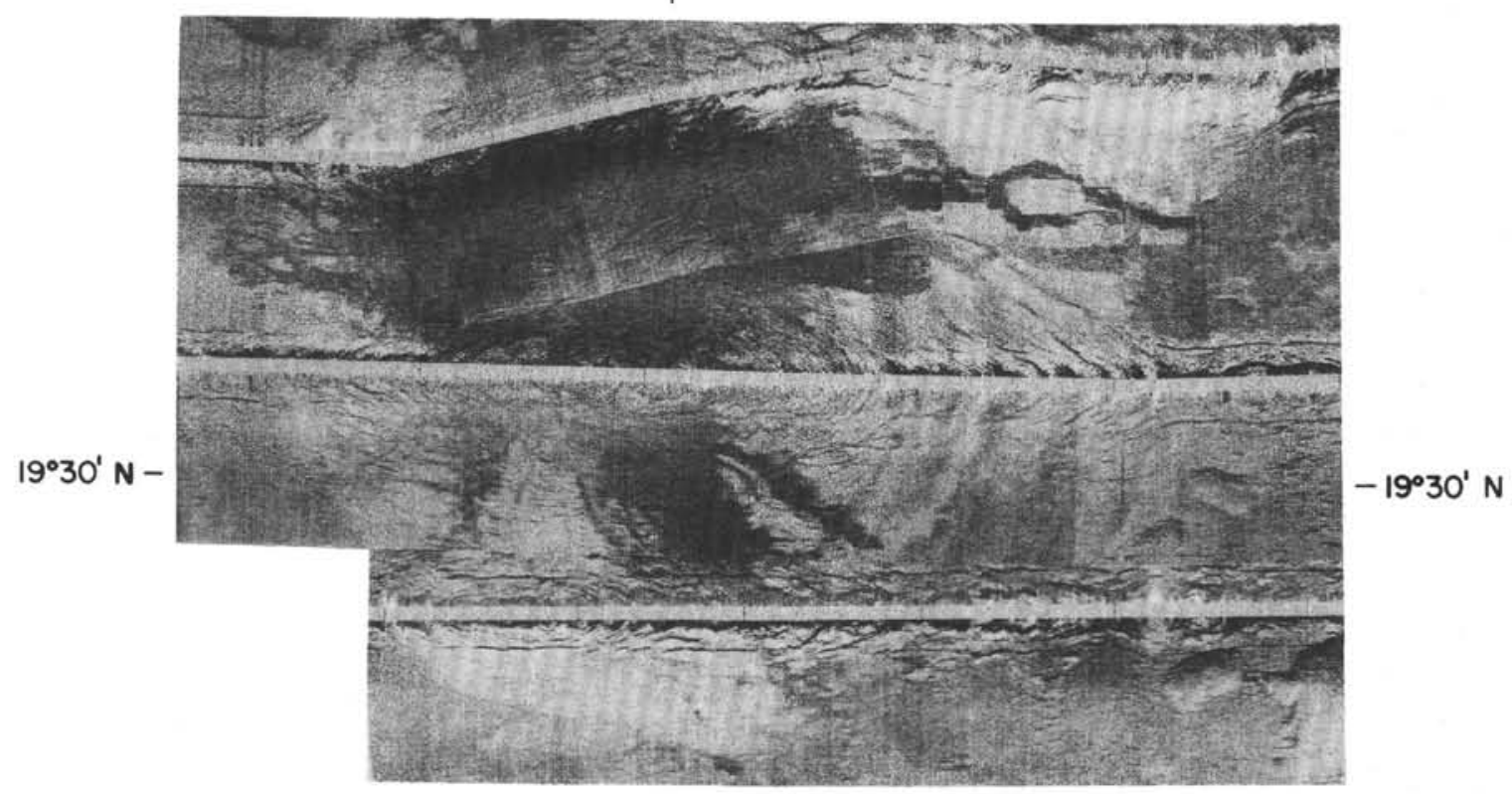

0

$10 \mathrm{KM}$

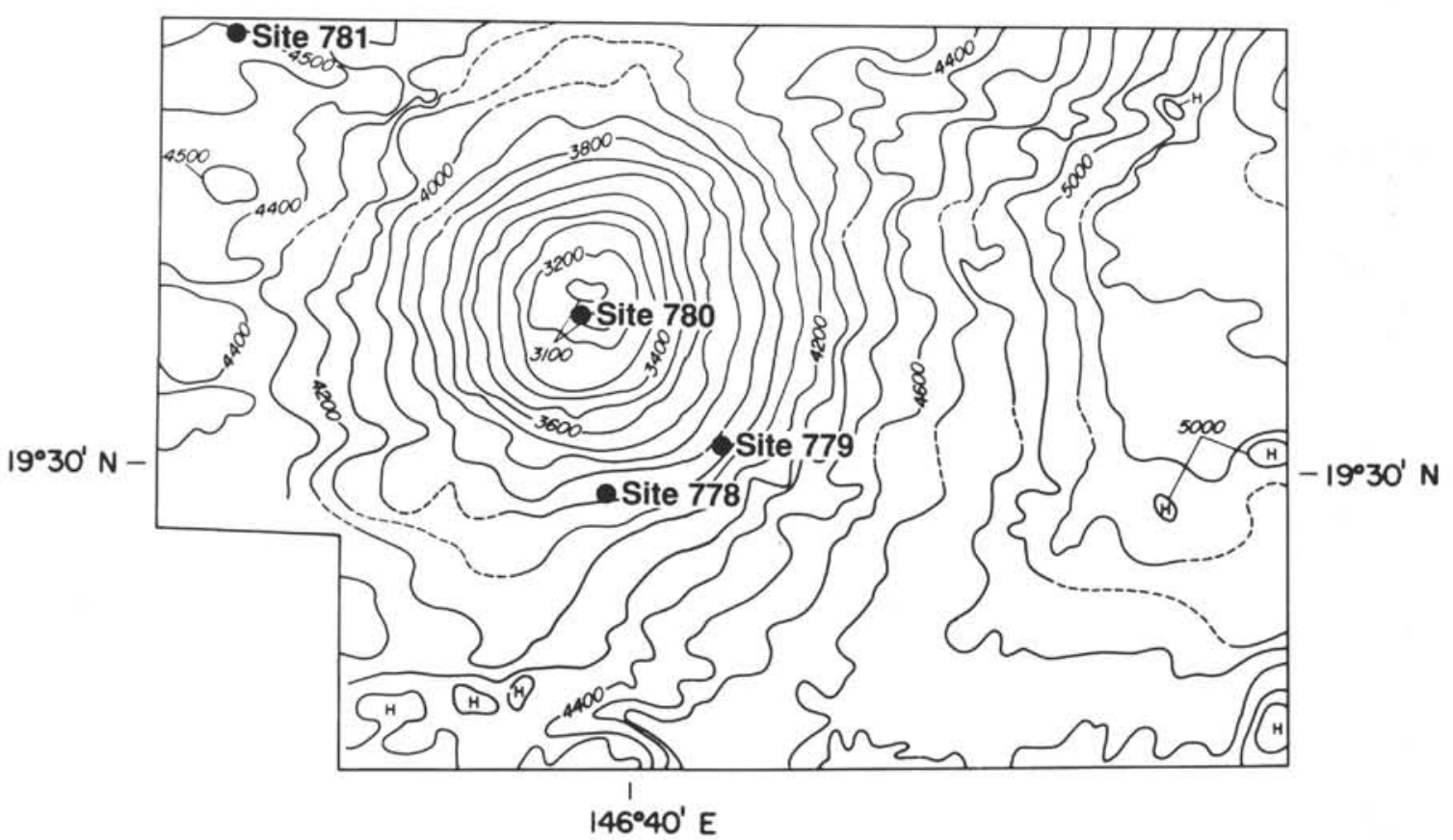

Figure 2. Locations of Leg 125 drill sites on Conical Seamount in the Mariana forearc.

several samples serpentinization may have affected orthopyroxene more than olivine.

In hand specimens, the serpentinized and tectonized dunites are generally massive, vary from deep greenish-black to dun-brown, and sometimes grade to fresh harzburgite over distances of a few millimeters. The primary mineralogy consists of $90 \%-99 \%$ olivine, $1 \%-$ $9 \%$ orthopyroxene, and up to $1 \%$ chromium-spinel (Table 1). Most dunites have been extensively serpentinized and exhibit mesh texture and splays of antigorite. The dunites also are cut by numerous serpentine-rich veins. Some samples contain crudely aligned, elongate (less than $15 \mathrm{~mm}$ ), and irregularly shaped olivine that tends to form a sheared fabric. Microgranulation of olivine, kink-banding in bastite, elongation of spinel, and deformation of clinopyroxene exsolution lamellae in orthopyroxene all provide evidence of penetrative deformation. An unusually large amount of fresh olivine persists in a few samples (Table 1), despite transformation of almost all of the 
Table 1. Modal mineralogy of ultramafic rocks from Conical Seamount, Leg 125 samples.

\begin{tabular}{|c|c|c|c|c|c|c|c|c|c|c|c|}
\hline $\begin{array}{l}\text { Sample } \\
\text { site-core }\end{array}$ & interval & p\# & $\begin{array}{l}\text { rock } \\
\text { name }\end{array}$ & $\begin{array}{l}\text { olivine } \\
\text { extant }\end{array}$ & $\begin{array}{c}\text { olivine } \\
\text { original }\end{array}$ & $\begin{array}{c}\text { opx } \\
\text { extant }\end{array}$ & $\begin{array}{c}\text { opx } \\
\text { original }\end{array}$ & $\begin{array}{c}\text { cpx } \\
\text { extant }\end{array}$ & $\begin{array}{c}\mathrm{cpx} \\
\text { original }\end{array}$ & $\begin{array}{c}s p \\
\text { extant }\end{array}$ & $\begin{array}{c}\mathrm{sp} \\
\text { original }\end{array}$ \\
\hline $125-778 \mathrm{~A}-2 \mathrm{R}-1$ & $57-59$ & 2 & SH & $<0.1$ & 85 & 5 & 15 & $0.2-0.3$ & $0.2-0.3$ & $0.5-1$ & $0.5-1$ \\
\hline $125-778 \mathrm{~A}-2 \mathrm{R}-1$ & $74-75$ & 5 & $\mathrm{SH}$ & 8 & 90 & 8 & 10 & $<0.1$ & $<0.1$ & 0.5 & 0.5 \\
\hline $125-778 \mathrm{~A}-2 \mathrm{R}-1$ & $78-81$ & 6 & SH & 10 & 80 & 15 & 20 & $<0.1$ & $<0.1$ & 0.5 & 0.5 \\
\hline $125-778$ A-7R-1 & $12-16$ & & SH & 0 & 70 & 1 & 29 & 0 & 0 & 1 & 1 \\
\hline $125-778 \mathrm{~A}-7 \mathrm{R}-1$ & $13-16$ & & $\mathrm{SH}$ & 0 & 80 & $<1$ & 19 & 0 & 0 & $<1$ & i \\
\hline $125-778 \mathrm{~A}-7 \mathrm{R}-1$ & $25-28$ & & SH & 0 & $85-90$ & 0 & $10-15$ & 0 & 0 & $<1$ & 1 \\
\hline 125-778A-7R-2 & $55-60$ & & SH & $<0.01$ & 85 & $<1$ & $15 ?$ & 0 & 0 & $<1$ & $<1$ \\
\hline $125-778 \mathrm{~A}-7 \mathrm{R}-2$ & $74-75$ & & $\mathrm{SH}$ & 0 & $72-77$ & 0 & $20-25$ & 0 & 0 & $<1$ & 3 \\
\hline $125-778 \mathrm{~A}-7 \mathrm{R}-\mathrm{CC}$ & $0-2$ & & $\mathrm{SH}$ & 0 & $77-82$ & 0 & $15-20$ & 0 & 0 & 2 & 3 \\
\hline $125-778 \mathrm{~A}-7 \mathrm{R}-\mathrm{CC}$ & $0-3$ & & SH & 0 & $70-80$ & 0 & $20-25$ & 0 & 0 & $2-3$ & 3 \\
\hline $125-778 \mathrm{~A}-8 \mathrm{R}-1$ & $39-40$ & 7 & $\mathrm{SH}$ & 0 & $75-82$ & $1-2$ & $15-20$ & tr & 1.2 & $2-3$ & $2-3$ \\
\hline $125-778 \mathrm{~A}-8 \mathrm{R}-1$ & $47-48$ & 8 & SH & 0 & 85 & 0 & 14 & 0 & 0 & 1 & 1 \\
\hline $125-778 \mathrm{~A}-9 \mathrm{R}-1$ & $57-58$ & & ASH & 0 & 90 & 0 & 10 & 0 & 0 ? & $i$ & i \\
\hline $125-778 \mathrm{~A}-12 \mathrm{R}-2$ & $43-45$ & & SH & 0 & $75-80$ & 0 & $18-23$ & 0 & 0 & 2 & 2 \\
\hline $125-778 \mathrm{~A}-12 \mathrm{R}-2$ & $73-75$ & & SH & 0 & 73-78 & $<1$ & $20-25$ & 0 & 0 & $i$ & 2 \\
\hline $125-779 \mathrm{~A}-3 \mathrm{R}-\mathrm{CC}$ & $13-15$ & 2 & SD & 20 & 94 & 0 & 5 & 0 & 0 & 0.1 & 1 \\
\hline $125-779 \mathrm{~A}-4 \mathrm{R}-1$ & $27-30$ & 3 & $\mathrm{SH}$ & 0 & 78.5 & $<1$ & 20 & tr & to & 1.5 & 1.5 \\
\hline $125-779 \mathrm{~A}-4 \mathrm{R}-1$ & $42-44$ & 5 & SH & 0 & $83-88$ & 0 & $10-15$ & 0 & 0 & 2 & 2 \\
\hline 125-779A-5R-1 & $108-109$ & 12 & SD & 10 & 88 & 5 & 10 & $<1$ & 1 & 0.5 & 1.5 \\
\hline $125-779$ A-5R-2 & $14-15$ & 3 & ASH & 0 & $83-89$ & 0 & $10-15$ & 0 & 0 & $1-2$ & $1-2$ \\
\hline $125-779$ A-5R-2 & $34-37$ & 3 & STH & $15-20$ & $84-89$ & 3.5 & $10-15$ & tr & tr & 0.5 & 1 \\
\hline 125-779A-5R-2 & $40-43$ & 3 & SH & $<1$ & 83-88 & 1.2 & $10-15$ & $<1$ & $<1$ & 2 & 2 \\
\hline $125-779$ A-5R-2 & $65-69$ & 4 & SD & 0 & 99 & 0 & 0 & 0 & 0 & $i$ & i \\
\hline $125-779 \mathrm{~A}-5 \mathrm{R}-2$ & $116-120$ & $10 \mathrm{a}$ & SH & $8-10$ & $78-83$ & 2 & $15-20$ & tr & tr & 1.2 & 2 \\
\hline $125-779 \mathrm{~A}-6 \mathrm{R}-1$ & $18-20$ & 2 & $\mathrm{SH}$ & $15-20$ & $77-82$ & $10-15$ & $15-20$ & 1 & 1? & 2 & 2 \\
\hline $125-779 \mathrm{~A}-8 \mathrm{R}-1$ & $27-29$ & $5 \mathrm{a}$ & ASH & 0 & $84-80$ & 0 & $10-15$ & 0 & 0 & 0.5 & 1 \\
\hline $125.779 \mathrm{~A}-8 \mathrm{R}-1$ & $57-60$ & $5 b$ & $\mathrm{SH}$ & 0 & 78 & 0 & 20 & 0 & 0 & 2 & 2 \\
\hline $125-779 \mathrm{~A}-8 \mathrm{R}-1$ & $82-83$ & $8 a$ & STD & $45-50$ & 93 & 4 & 5 & tr & tr & 2 & 2 \\
\hline $125-779 \mathrm{~A}-8 \mathrm{R}-1$ & $90-93$ & $8 \mathrm{~b}$ & STD & $40-50$ & 96 & 2 & 3 & 0 & 0 & 0.5 & I \\
\hline $125-779 \mathrm{~A}-9 \mathrm{R}-2$ & $52-54$ & $4 \mathrm{~b}$ & STH & 25 & $85-87$ & 10 & $10-12$ & 0 & 0 & 1.5 & 1.5 \\
\hline $125-779 \mathrm{~A}-10 \mathrm{R}-1$ & $26-29$ & 3 & STD? & 55 & 94 & 1 & 5 & $<0.1$ & $<0.1$ & 0.5 & 1 \\
\hline $125-779 \mathrm{~A}-10 \mathrm{R}-1$ & $39-43$ & 5 & STD & 40 & 97 & 2 & 3 & 0 & 0 & 0.5 & i \\
\hline $125-779 \mathrm{~A}-10 \mathrm{R}-1$ & $54-57$ & 6 & STD & 50 & 97 & 2 & 3 & 0 & 0 & 0.5 & i \\
\hline $125-779 \mathrm{~A}-10 \mathrm{R}-2$ & $28-31$ & 1 & SH & 0 & 88 & 0 & 12 & 0 & 0 & tr & $<1$ \\
\hline $125-779 \mathrm{~A}-11 \mathrm{R}-1$ & $6-9$ & 2 & SH & $<1$ & 87 & 0 & 12 & tr & ir & 1 & 1 \\
\hline $125-779 \mathrm{~A}-11 \mathrm{R}-1$ & $14-18$ & 3 & SH & tr? & 82 & 0 & 15 & 1.5 & 1.5 & 1.5 & 1.5 \\
\hline 125-779A-1IR-1 & $34-36$ & 5 & SD & 0 & 99 & 0 & 0 & 0 & 0 & tr & 1 \\
\hline $125-779 \mathrm{~A}-12 \mathrm{R}-1$ & $38-42$ & 6 & SH & 10 & 86 & 8 & 12 & 1 & I & 1 & 1 \\
\hline $125-779 \mathrm{~A}-13 \mathrm{R}-1$ & $2-5$ & 1 & SH & 0 & 87 & 0 & 12 & 0 & 0 & $<1$ & 1 \\
\hline $125-779 \mathrm{~A}-13 \mathrm{R}-2$ & $50-54$ & 1 & SH & $20-25$ & 79.84 & $10-15$ & $15 \cdot 20$ & $<1$ & $<1$ & $<1$ & i \\
\hline $125-779 \mathrm{~A}-13 \mathrm{R}-3$ & $9-11$ & 1 & $\mathrm{SH}$ & 50 & 86 & 5 & 12 & tr & tr & 1 & 2 \\
\hline $125-779 \mathrm{~A}-14 \mathrm{R}-1$ & $74-77$ & $5 \mathrm{a}$ & SD & 40 & 91 & 2 & 8 & $<1$ & $<1$ & 1 & 1 \\
\hline $125-779 \mathrm{~A}-14 \mathrm{R}-2$ & $2 \mathrm{I}-24$ & 3 & SD & $20-25$ & 95 & $i$ & 3 & $<0.1$ & $<0.1$ & 1 & 2 \\
\hline $125-779 \mathrm{~A}-14 \mathrm{R}-2$ & $77-79$ & 8 & $\mathrm{SH}$ & 45 & $80-85$ & $10-15$ & $15-20$ & 3 & 3 & 2 & 2 \\
\hline $125-779 \mathrm{~A}-14 \mathrm{R}-2$ & $|39-14|$ & 16 & $\mathrm{SH}$ & 40 & $78-83$ & 10 & $15-20$ & $<1$ & $<1$ & $i$ & 1.5 \\
\hline $125-779 \mathrm{~A}-15 \mathrm{R}-1$ & $15-17$ & 4 & SH & 33 & $83-85$ & 12 & 12 & 3 & 3 & $i$ & 2 \\
\hline $125-779 \mathrm{~A}-15 \mathrm{R}-2$ & $18-20$ & 3 & $\mathrm{SH}$ & 21 & 87 & 7 & 12 & $<1$ & $<1$ & $i$ & i \\
\hline $125-779 \mathrm{~A}-15 \mathrm{R}-2$ & $24-27$ & 3 & SD & 10 & 94-97 & 0 & $2-5$ & 0 & 0 & 0.3 & i \\
\hline $125-779 \mathrm{~A}-15 \mathrm{R}-2$ & $37-40$ & 5 & SH & 40 & 81 & 10 & is & 1 & $i$ & 3 & 3 \\
\hline $125-779 \mathrm{~A}-15 \mathrm{R}-2$ & $110-111$ & 17 & SD & 54 & 97 & tr & tr & 0 & 0 & 1 & 2 \\
\hline $125-779 \mathrm{~A}-16 \mathrm{R}-1$ & $16-19$ & 3 & SH & 50 & 86 & 7 & 12 & 0 & 0 & $i$ & 2 \\
\hline $125-779 \mathrm{~A}-16 \mathrm{R}-1$ & $19-23$ & 3 & $\mathrm{D}$ & $76-81$ & 95 & 2 & 3 & $<1$ & $<1$ & 0.5 & 1.5 \\
\hline $125-779 \mathrm{~A}-16 \mathrm{R}-1$ & $37-40$ & 6 & $\mathrm{H}$ & 69 & 83 & 7 & 15 & $<1$ & $<1$ & $<1$ & 2 \\
\hline $125-779 A-16 R-1$ & $50-52$ & 8 & $\mathrm{H}$ & 68 & 84 & 7 & is & $<1$ & $<1$ & $<1$ & $i$ \\
\hline $125-779 \mathrm{~A}-16 \mathrm{R}-1$ & $127-129$ & 19 & SD & 52 & 90 & 3 & 8 & tr & tr & $i$ & 2 \\
\hline 125-779A-16R-2 & $44-47$ & 6 & $\mathrm{SH}$ & 18 & 81 & 5 & 12 & 5 & 5 & i & 2 \\
\hline $125-779 \mathrm{~A}-16 \mathrm{R}-2$ & $61-64$ & 9 & $\mathrm{SH}$ & 20 & 85 & 10 & 12 & 2 & 2 & i & $i$ \\
\hline $125-779 \mathrm{~A}-16 \mathrm{R}-2$ & $74-77$ & 9 & $\mathrm{H}$ & 48 & 76.5 & 12 & 20 & 2 & 2 & 1 & 1.5 \\
\hline $125-779 \mathrm{~A}-16 \mathrm{R}-2$ & $117-120$ & 11 & $\mathrm{SH}$ & 12 & 83 & 10 & 15 & $i$ & $i$ & $i$ & 1 \\
\hline $125-779 \mathrm{~A}-17 \mathrm{R}-1$ & $144-145$ & 17 & SD & 31 & 98 & 0 & 0 & 0 & 0 & i & 2 \\
\hline $125-779 \mathrm{~A}-17 \mathrm{R}-2$ & $17-20$ & 3 & $\mathrm{H}$ & 48 & 73 & 15 & 25 & tr & tr & $i$ & 2 \\
\hline $125-779 \mathrm{~A}-17 \mathrm{R}-2$ & $21-24$ & 3 & $\mathrm{H}$ & 47 & 74 & 20 & 25 & tr & tr & $i$ & j \\
\hline $125-779 \mathrm{~A}-17 \mathrm{R}-3$ & $77-80$ & $8 \mathrm{~b}$ & $\mathrm{H}$ & 53 & 83 & 10 & 15 & tr & ir & 1 & 2 \\
\hline $125-779 \mathrm{~A}-17 \mathrm{R}-3$ & $80-83$ & $8 \mathrm{~b}$ & $\mathrm{H}$ & 43 & 83 & 10 & is & $<1$ & $<1$ & $\mathrm{i}$ & 2 \\
\hline $125-779 \mathrm{~A}-17 \mathrm{R}-4$ & $44-47$ & 4 & SH & 27.5 & 87 & 7 & 12 & tr & tr & 0.5 & $i$ \\
\hline $125-779 \mathrm{~A}-19 \mathrm{R}-2$ & $97-99$ & 13 & D & 61.5 & 99 & 0 & 0 & 0 & 0 & 0.5 & i \\
\hline $125-779 \mathrm{~A}-22 \mathrm{R}-1$ & $58-60$ & iI & ASH & tr & 84 & 1 & 15 & 0 & 0 & 1 & i \\
\hline $125-779 \mathrm{~A}-22 \mathrm{R}-1$ & $63-65$ & II & $\mathrm{SH}$ & 35 & 79 & 12 & 20 & 0 & 0 & $<1$ & i \\
\hline $125-779 \mathrm{~A}-22 \mathrm{R}-2$ & $18-20$ & 2 & SD & 15 & 99 & 0 & 0 & 0 & 0 & 0.5 & 1 \\
\hline $125-779 \mathrm{~A}-22 \mathrm{R}-3$ & $55-57$ & 7 & SD & 35 & 91 & 3 & 7 & 0 & 0 & 1 & 2 \\
\hline | $25-779 \mathrm{~A}-24 \mathrm{R}-1$ & $36-38$ & 6 & SD & 0 & 93 & 0 & 7 & 0 & 0 & $<1$ & $<1$ \\
\hline $125-779 \mathrm{~A}-25 \mathrm{R}-1$ & $85-87$ & $10 \mathrm{~b}$ & SD & 20 & 99 & 0 & tr & 0 & 0 & 0.5 & 1 \\
\hline $125-779 \mathrm{~A}-26 \mathrm{R}-2$ & $50-52$ & $2 \mathrm{~b}$ & $\mathrm{H}$ & 48 & 81 & is & 18 & $<1$ & $<1$ & 1 & 1.5 \\
\hline 125-779A-26R-2 & $71-75$ & $2 c$ & ASH & 2 & 86 & 2 & 12 & tr & tr & $i$ & 2 \\
\hline $125-779 \mathrm{~A}-26 \mathrm{R}-3$ & $101-103$ & $3 \mathrm{~b}$ & $\mathrm{SH}$ & 21.5 & 62.5 & 25 & 35 & 1 & 1 & 1.5 & 1.5 \\
\hline 125-779A-28R-2 & $109-113$ & & ASD & 0 & 100 & 0 & 0 & 0 & 0 & ir & tr \\
\hline $125-779$ A-28R-3 & $26-28$ & $2 \mathrm{a}$ & SH & tr & 83.5 & 0 & 15 & 0 & 0 & 1 & 1.5 \\
\hline $125-780 \mathrm{C}-6 \mathrm{R}-1$ & $61-62$ & $7 \mathrm{a}$ & $\mathrm{SH}$ & 21 & 78 & 15 & 20 & 1 & 1 & 1 & 1 \\
\hline $125-780 \mathrm{C}-8 \mathrm{R}-1$ & $98-101$ & 10 & SD & 38.5 & 92 & 0 & 7 & 0 & 0 & 0.5 & 1 \\
\hline $125-780 \mathrm{C}-10 \mathrm{R}-1$ & $13-16$ & 2 & STH & 15 & 76 & 20 & 22 & 0.5 & 0.5 & 1.5 & 1.5 \\
\hline $125-780 \mathrm{C}-10 \mathrm{R}-1$ & $36-37$ & 6 & SD & 0 & 96 & 0.5 & 3 & 0 & 0 & 0.5 & 1 \\
\hline $125-780 \mathrm{C}-10 \mathrm{R}-1$ & $36-37$ & 6 & SD & 0 & 89.5 & 0 & 9 & 0 & 0 & 1.5 & 1.5 \\
\hline $125-780 \mathrm{C}-16 \mathrm{R}-1$ & $53-59$ & 7 & $\mathrm{SH}$ & 20 & 74 & 15 & 24.5 & tr & tr & 0.5 & 0.5 \\
\hline $125-780 \mathrm{C}-18 \mathrm{R}-1$ & $60-61$ & $2 \mathrm{a}$ & SH & 15 & 76.5 & 12 & 20 & 1.5 & 1.5 & 1.5 & 2 \\
\hline $125-780 D-7 X-1$ & $25-26$ & & $\mathrm{~s}$ & 0 & ? & 0 & $?$ & 0 & 0 & 0 & ? \\
\hline $125-780 D-7 X-5$ & $94-96$ & & SH & 0 & 79 & 0 & 20 & 0 & 0 & 0.5 & 1 \\
\hline
\end{tabular}

$\mathrm{SD}=$ serpentinized dunite; $\mathrm{H}=$ harzburgite; $\mathrm{SH}=$ serpentinized harzburgite; $\mathrm{ASD}=$ altered serpentinized dunite; $\mathrm{ASH}=$ altered serpentinized harzburgite; $\mathrm{S}=$ serpentinite; opx = orthopyroxene; $\mathrm{cpx}=$ clinopyroxene; $\mathrm{sp}=$ spinel; $\mathrm{serp}=$ serpentine; $\mathrm{br}=$ brucite; $\mathrm{mt}=$ magnetite; $\mathrm{chl}$ = chlorite. 
Table 1 (continued).

\begin{tabular}{|c|c|c|c|c|}
\hline $\begin{array}{l}\text { Sample } \\
\text { site-core }\end{array}$ & $\mathrm{mt}$ & serp & other & $\begin{array}{c}\text { total } \\
\text { secondary }\end{array}$ \\
\hline $125-778 \mathrm{~A}-2 \mathrm{R}-1$ & 1 & 78 & $<1$ carb & 95 \\
\hline $125-778 \mathrm{~A}-2 \mathrm{R}-1$ & 3 & 50 & & 79.5 \\
\hline $125-778 \mathrm{~A}-2 \mathrm{R}-1$ & 2 & 52.5 & $<1-1$ carb & 74.5 \\
\hline $125-778 \mathrm{~A}-7 \mathrm{R}-1$ & 2 & 96 & & 98 \\
\hline 125-778A-7R-1 & 2 & 95 & & 99 \\
\hline $125-778 \mathrm{~A}-7 \mathrm{R}-1$ & 0 & $95-97$ & & $98-100$ \\
\hline $125-778 \mathrm{~A}-7 \mathrm{R}-2$ & 2 & 87 & & 99 \\
\hline $125-778 \mathrm{~A}-7 \mathrm{R}-2$ & 2 & 92 & & 99 \\
\hline 125-778A-7R-CC & 3 & 90 & & 98 \\
\hline $125-778 \mathrm{~A}-7 \mathrm{R}-\mathrm{CC}$ & 2 & $83-84$ & & $97-98$ \\
\hline 125-778A-8R-1 & 1 & $79-87$ & It sphene? & $95-97$ \\
\hline 125-778A-8R-1 & $1-2$ & $92-93$ & & 99 \\
\hline $125-778 \mathrm{~A}-9 \mathrm{R}-1$ & 0 & $80-90$ & & 99 \\
\hline $125-778 \mathrm{~A}-12 \mathrm{R}-2$ & $1-2$ & $85-87$ & 10 thulite? & 98 \\
\hline $125-778 \mathrm{~A}-12 \mathrm{R}-2$ & 2 & 93-95 & & 99 \\
\hline $125-779 \mathrm{~A}-3 \mathrm{R}-\mathrm{CC}$ & 1 & $70-75$ & & 80 \\
\hline $125-779 \mathrm{~A}-4 \mathrm{R}-1$ & 1 & 87 & & 98 \\
\hline $125-779 \mathrm{~A}-4 \mathrm{R}-1$ & $<1$ & 88 & & 98 \\
\hline $125-779 \mathrm{~A}-5 \mathrm{R}-1$ & 2 & $72-77$ & & 84.5 \\
\hline $125-779 \mathrm{~A}-5 \mathrm{R}-2$ & $<1$ & $38-49$ & & $98-99$ \\
\hline $125-779 \mathrm{~A}-5 \mathrm{R}-2$ & 1 & $69-76$ & & $74.5-81.5$ \\
\hline $125-779 \mathrm{~A}-5 \mathrm{R}-2$ & 1 & 91 & & 96 \\
\hline $125-779 \mathrm{~A}-5 \mathrm{R}-2$ & $1-2$ & $97-98$ & & 99 \\
\hline $125-779 \mathrm{~A}-5 \mathrm{R}-2$ & 1 & 79.81 & & $86-89$ \\
\hline $125-779 \mathrm{~A}-6 \mathrm{R}-1$ & 1 & $58-68$ & & $62-72$ \\
\hline $125-779 \mathrm{~A}-8 \mathrm{R}-1$ & 2 & 77 & & 99.5 \\
\hline $125-779 \mathrm{~A}-8 \mathrm{R}-1$ & 0 & $57-67$ & & 98 \\
\hline $125-779 \mathrm{~A}-8 \mathrm{R}-1$ & 2 & 44.49 & & $46-51$ \\
\hline $125-779 \mathrm{~A}-8 \mathrm{R}-1$ & $<1$ & $42-52$ & & $47-57$ \\
\hline 125-779A-9R-2 & 1 & 68.5 & & 72.5 \\
\hline $125-779 \mathrm{~A}-10 \mathrm{R}-1$ & 3 & 37 & & 43 \\
\hline $125-779 \mathrm{~A}-10 \mathrm{R}-1$ & 2 & 51 & I carb & 57.5 \\
\hline $125-779 \mathrm{~A}-10 \mathrm{R}-1$ & 2 & 42 & & 47.5 \\
\hline $125-779 \mathrm{~A}-10 \mathrm{R}-2$ & $<1$ & 96 & & 99 \\
\hline $125-779 \mathrm{~A}-11 \mathrm{R}-1$ & $<1$ & 98 & & 99 \\
\hline $125-779 \mathrm{~A}-11 \mathrm{R}-1$ & $<1$ & 97 & & 97 \\
\hline $125-779 A-1 \mid R-1$ & to & 100 & & 100 \\
\hline $125-779 \mathrm{~A}-12 \mathrm{R}-1$ & $<1$ & 78 & & 80 \\
\hline 125-779A-13R-1 & $<1$ & 95 & & 99 \\
\hline $125-779 \mathrm{~A}-13 \mathrm{R}-2$ & 2 & $54-64$ & & $58-68$ \\
\hline $125-779 A-13 R-3$ & 1 & 42 & & 44 \\
\hline $125-779 \mathrm{~A}-14 \mathrm{R}-1$ & 1 & 54 & & 57 \\
\hline $125-779 A-14 R-2$ & 1 & $67-72$ & & $73-78$ \\
\hline $125-779 \mathrm{~A}-14 \mathrm{R}-2$ & $<1$ & $30-35$ & & $30-35$ \\
\hline $125-779 \mathrm{~A}-14 \mathrm{R}-2$ & 1 & 45 & & 49 \\
\hline $125-779 \mathrm{~A}-15 \mathrm{R}-1$ & 1 & 50 & & 51 \\
\hline $125-779 A-15 R-2$ & 1 & 70 & & 71 \\
\hline 125-779A-15R-2 & 2 & 82 & & 89.7 \\
\hline $125-779 \mathrm{~A}-15 \mathrm{R}-2$ & 1 & 45 & & 46 \\
\hline $125-779 \mathrm{~A}-15 \mathrm{R}-2$ & 2 & 40 & & 45 \\
\hline 125-779A-16R-1 & 2 & 40 & & 42 \\
\hline 125-779A-16R-1 & 1 & $15-20$ & & $|6-3|$ \\
\hline $125-779 \mathrm{~A}-16 \mathrm{R}-1$ & 2 & 25 & 4 talc? & 31 \\
\hline 125-779A-16R-1 & 1 & 20 & 3 talc? & 24 \\
\hline 125-779A-16R-1 & 1 & 40 & 2 talc? & 44 \\
\hline 125-779A-16R-2 & 1 & 70 & & 71 \\
\hline $125-779 \mathrm{~A}-16 \mathrm{R}-2$ & 1 & 65 & & 67 \\
\hline $125-779 A-16 R-2$ & 1 & 35 & & 37 \\
\hline $125-779 A-16 R-2$ & 1 & 75 & & 76 \\
\hline $125-779 \mathrm{~A}-17 \mathrm{R}-1$ & 1 & 65 & & 68 \\
\hline $125-779 \mathrm{~A}-17 \mathrm{R}-2$ & 1 & 35 & & 36 \\
\hline $125-779 \mathrm{~A}-17 \mathrm{R}-2$ & 2 & 30 & & 32 \\
\hline $125-779 \mathrm{~A}-17 \mathrm{R}-3$ & 1 & 35 & & 36 \\
\hline $125-779 \mathrm{~A}-17 \mathrm{R}-3$ & 1 & 45 & & 46 \\
\hline $125-779 \mathrm{~A}-17 \mathrm{R}-4$ & 1 & 65 & & 66 \\
\hline $125-779 \mathrm{~A}-19 \mathrm{R}-2$ & 2 & 35 & & 38 \\
\hline $125-779 \mathrm{~A}-22 \mathrm{R}-1$ & 1 & 70 & & 98 \\
\hline $125-779 \mathrm{~A}-22 \mathrm{R}-1$ & 1 & 50 & & 53 \\
\hline $125-779 \mathrm{~A}-22 \mathrm{R}-2$ & 2 & 77.5 & & 84.5 \\
\hline $125-779 A-22 R-3$ & 1 & 60 & & 61 \\
\hline $125-779 \mathrm{~A}-24 \mathrm{R}-1$ & tr & 93 & & 100 \\
\hline 125-779A-25R-1 & 1 & 78 & & 79 \\
\hline $125-779 A-26 R-2$ & 1 & 35 & & 36 \\
\hline $125-779 A-26 R-2$ & 2 & 63 & & 95 \\
\hline $125-779 A-26 R-3$ & 1 & 50 & & 51 \\
\hline $125-779 A-28 R-2$ & 1 & $78-83$ & & 100 \\
\hline 125-779A-28R-3 & $<1$ & 93 & & 99 \\
\hline $125-780 \mathrm{C}-6 \mathrm{R}-1$ & 1 & 60 & & 63 \\
\hline $125-780 \mathrm{C}-8 \mathrm{R}-1$ & 1 & 55 & 3 talc & 61 \\
\hline $125-780 \mathrm{C}-10 \mathrm{R}-1$ & $<1$ & 62 & & 63 \\
\hline $125-780 \mathrm{C}-10 \mathrm{R}-1$ & 8 & 90.6 & & 99 \\
\hline $125-780 \mathrm{C}-10 \mathrm{R}-1$ & 1.5 & 96.5 & & 98.5 \\
\hline $125-780 \mathrm{C}-16 \mathrm{R}-1$ & 1 & 63.5 & & 64.5 \\
\hline $125-780 \mathrm{D}-18 \mathrm{R}-1$ & 1 & 67 & 1 talc & 80 \\
\hline $125-780 \mathrm{D}-7 \mathrm{X}-1$ & 3 & 94 & & 100 \\
\hline $125-780 C-7 X-5$ & $<1$ & 99 & & 99.5 \\
\hline
\end{tabular}

orthopyroxene to serpentine. Spinel has been completely altered to magnetite in the serpentinized portions. Other secondary minerals include chlorite and brucite (Fryer, Pearce, Stokking, et al., 1990).

Two clasts of talc-bearing serpentine were recovered in Hole 778A. They are light greenish-white, have a soapy feel, and are soft (Mohs' scale hardness of 2). The mineralogy is essentially talc and serpentine, with trace amounts of chromium-spinel.

The degree of metamorphism and of secondary or tertiary alterations in the ultramafic clasts shows systematic but subtle variation between and within holes. The samples from Holes 778A are generally highly metamorphosed and affected by alteration containing numerous veins and abundant evidence of retrograde metamorphism. All samples contain more than about $75 \%$ secondary (including metamorphic) minerals, and $87 \%$ of the samples contain more than $95 \%$ of secondary minerals. The degree of serpentinization varies in ultramafic clasts from Site 779, but generally decreases downhole to a depth of approximately 125 mbsf (Core 125-779A-16R). It increases again from about 170 mbsf (Core 125-779A-22R) to at least $235 \mathrm{mbsf}$ (Core 125-779A-28R). Thus, the freshest samples are from Cores 125-779A-16R through 19R (135-170 mbsf). The ultramafic clasts from the holes drilled at the summit are predominantly serpentinized harzburgite and are nearly uniform in composition, but the clasts do show a general increase in degree of metamorphism and alteration with depth. These rocks are moderately to highly altered $(61 \%$ to $100 \%)$ and exhibit evidence of metamorphism characteristic of moderate temperature and pressure.

\section{Geochemistry of Ultramafic Clasts}

Shipboard X-ray fluorescence (XRF) analyses were performed for 36 samples of serpentinized, tectonized harzburgite and dunite clasts from Conical Seamount. Prior to analysis, samples were crushed in a Spex 8510 shatterbox using a tungsten carbide barrel. This produced some Ta and massive $\mathrm{W}$ contamination of the sample. A fully automated wavelength-dispersive ARL8420 XRF ( $3 \mathrm{~kW}$ ) system equipped with an Rh target X-ray tube was used to determine the abundance of major oxides and trace elements in whole-rock samples. Systematic errors resulting from short-term or long-term fluctuations in X-ray tube intensity were corrected by normalizing the measured intensities of the samples to those of a standard that is always run with a set of six samples. Loss on ignition (LOI) values were determined by drying the sample at $110^{\circ} \mathrm{C}$ for $8 \mathrm{hr}$ and weighing before and after ignition at $1030^{\circ} \mathrm{C}$. There is little variation in the major- and trace-element composition of the ultramafic rocks analyzed (Fryer, Pearce, Stokking, et al., 1990).

\section{Major Elements}

LOI of these samples ranges from 4.77 to $17.41 \mathrm{wt} \%$ and correlates positively with percentage of serpentinization. Although ranges of major-element concentrations are similar in dunite and harzburgite samples, some small distinctions exist reflecting mineralogical variations (Tables $2-4)$. In all rocks, $\mathrm{SiO}_{2}$ and $\mathrm{MgO}$ are inversely correlated with degree of serpentinization (Fryer, Pearce, Stokking, et al., 1990).

\section{Trace Elements}

Trace-element data are presented in Tables 2-4. Compatible element abundances are predictably high in both the dunite and harzburgite samples of all the holes, but the ranges of values vary between holes. There is no significant correlation between geochemical parameters and depth below the seafloor (Fryer, Pearce, Stokking, et al., 1990).

\section{XRD MINERALOGY STUDIES}

\section{Methods}

Only those ultramafic clasts analyzed for major- and trace-element analyses by XRF onboard ship were selected for our shore-based XRD 
Table 2. Major-element (in weight $\%$ oxides) and trace-element (in ppm) data for ultramafic rocks from Hole 778A.

\begin{tabular}{|c|c|c|c|c|c|c|c|c|}
\hline $\begin{array}{c}\text { Core: } \\
\text { Interval }(\mathrm{cm}):\end{array}$ & $\begin{array}{c}2 \mathrm{R}-1 \\
53-56\end{array}$ & $\begin{array}{c}2 \mathrm{R}-1 \\
89-92\end{array}$ & $\begin{array}{c}3 \mathrm{R}-\mathrm{CC} \\
1-7\end{array}$ & $\begin{array}{c}7 \mathrm{R}-2 \\
73-78\end{array}$ & $\begin{array}{c}7 \mathrm{R}-\mathrm{CC} \\
7-13\end{array}$ & $\begin{array}{c}8 R-1 \\
36-44\end{array}$ & $\begin{array}{c}12 \mathrm{R}-2 \\
43-45\end{array}$ & $\begin{array}{c}12 R-2 \\
73-75\end{array}$ \\
\hline $\mathrm{SiO}_{2}$ & 38.17 & 35.69 & 40.93 & 34.14 & 37.46 & 34.61 & 41.52 & 39.29 \\
\hline $\mathrm{TiO}_{2}$ & 0.00 & 0.00 & 0.00 & 0.00 & 0.00 & 0.00 & 0.00 & 0.00 \\
\hline $\mathrm{Al}_{2} \mathrm{O}_{3}$ & 0.74 & 0.00 & 1.09 & 0.85 & 0.76 & 0.68 & 0.71 & 1.01 \\
\hline $\mathrm{Fe}_{2} \mathrm{O}_{3}$ & 6.73 & 6.77 & 7.21 & 8.66 & 7.86 & 8.00 & 8.95 & 7.64 \\
\hline $\mathrm{MnO}$ & 0.10 & 0.10 & 0.10 & 0.14 & 0.13 & 0.16 & 0.08 & 0.06 \\
\hline $\mathrm{MgO}$ & 36.59 & 35.88 & 36.85 & 39.32 & 39.15 & 39.21 & 39.61 & 37.04 \\
\hline $\mathrm{CaO}$ & 0.07 & 3.52 & 0.74 & 0.02 & 0.03 & 0.08 & 0.06 & 0.07 \\
\hline $\mathrm{Na}_{2} \mathrm{O}$ & 0.09 & 0.09 & 0.00 & 0.09 & 0.00 & 0.00 & 0.00 & 0.00 \\
\hline $\mathrm{K}_{2} \mathrm{O}$ & 0.01 & 0.00 & 0.01 & 0.01 & 0.05 & 0.00 & 0.00 & 0.00 \\
\hline $\mathrm{P}_{2} \mathrm{O}_{5}$ & 0.00 & 0.01 & 0.00 & 0.00 & 0.00 & 0.00 & 0.00 & 0.00 \\
\hline LOI & 15.06 & 15.55 & 11.49 & 14.76 & 13.66 & 16.06 & 6.01 & 11.99 \\
\hline $\mathrm{NiO}$ & 0.29 & 0.39 & 0.28 & 0.39 & 0.36 & 0.33 & 0.36 & 0.37 \\
\hline $\mathrm{Cr}_{2} \mathrm{O}_{3}$ & 0.36 & 0.07 & 0.37 & 0.41 & 0.33 & 0.37 & 0.42 & 0.53 \\
\hline Total & 98.20 & 98.08 & 99.08 & 98.79 & 99.79 & 99.50 & 97.70 & 98.00 \\
\hline $\mathrm{Nb}$ & tr & tr & tr & tr & tr & tr & tr & tr \\
\hline $\mathrm{Zr}$ & 1 & 2 & 0 & 1 & 1 & 1 & 0 & 1 \\
\hline $\mathrm{Y}$ & 0 & nd & 1 & nd & nd & nd & 1 & nd \\
\hline $\mathrm{Sr}$ & 9 & 595 & 5 & 2 & 3 & 8 & 9 & 12 \\
\hline $\mathrm{Rb}$ & 0 & nd & 1 & nd & 1 & 1 & nd & 0 \\
\hline $\mathrm{Zn}$ & 52 & 28 & 36 & 39 & 42 & 64 & 42 & 40 \\
\hline $\mathrm{Cu}$ & 3 & 3 & 11 & 2 & 2 & 4 & 8 & 2 \\
\hline $\mathrm{Ni}$ & 2281 & 3039 & 2173 & 3034 & 2818 & 2638 & 2813 & 2905 \\
\hline $\mathrm{Cr}$ & 2496 & 501 & 2523 & 2786 & 2261 & 2510 & 2866 & 3603 \\
\hline V & 46 & 22 & 40 & 38 & 41 & 48 & 48 & 62 \\
\hline $\mathrm{Ti}$ & 0 & 0 & 0 & 0 & 0 & 0 & 0 & 0 \\
\hline $\mathrm{Ce}$ & tr & tr & nd & tr & nd & nd & tr & nd \\
\hline $\mathrm{Ba}$ & tr & nd & tr & nd & nd & 10 & nd & nd \\
\hline
\end{tabular}

Oxide and elemental abundances are from whole-rock analyses by $\mathrm{XRF} ; \mathrm{LOI}=10$ ss on ignition between $150^{\circ} \mathrm{C}$ and $1030^{\circ} \mathrm{C}$; $\mathrm{t}=$ below detection limits $(<5 \mathrm{ppm}$ for $\mathrm{Nb} ;<10 \mathrm{ppm}$ for $\mathrm{Ba}$ and $\mathrm{Ce})$; nd = not detected (background count was greater than sample count).

studies. Samples were selected onboard ship primarily at changes in lithology. Thus, these samples are representative of the range in lithology within the cores, but not necessarily of the volume distribution of rock types within the holes.

X-ray diffraction (XRD) analysis of selected samples was performed to clarify questions regarding the presence and composition of several major and minor phases and to gain a more thorough understanding of possible stratigraphic relationships. All analyses were performed using the University of Hawaii X-ray diffractometer, integrated with a Data General data collection system interfaced with an Apple Macintosh SE computer. The XRD utilizes a solid-state Ge detector and a $\mathrm{Cu} \mathrm{K} \alpha$ radiation source; the computer strips $\mathrm{K} \alpha-2$ using only the $\mathrm{K} \alpha-1$ emission. The instrument was run at $1^{\circ}$ from $2^{\circ}$ to $70^{\circ} 2 \theta$. Tube current was at $40 \mathrm{~mA}$ and voltage at $45 \mathrm{kV}$. Crystal slits and settings were used. The peaks were identified with the Scintag Pad V Peakfinder program.

In Tables 5-8 a given mineral is designated definitely present (large open circle) if all three main peaks are present, probably present (large open circle with a slash) if two of the main peaks are present, and possibly present (small open circle) if one of the main peaks is present.

\section{Results}

The samples range in degree of replacement of primary minerals by metamorphic or alteration processes. The group of freshest samples, Group 1 has less than $45 \%$ metamorphic and secondary minerals based on thin section inspection (Table 5). Group 2 samples contain $46 \%$ to $89 \%$ metamorphic and secondary minerals (Table 6). Group 3 consists of ultramafic clasts in which more than $90 \%$ of the original minerals have been replaced (Table 7).

Group 1 samples are the six freshest ultramafic clasts analyzed. Samples 125-779A-16R-1 (Piece 3, 19-23 cm) and 125-779A-19R-2 (Piece 13b, 97-99 cm) are dunite, and the rest (125-779A-16R-2 (Piece 9, 74-77 cm), 125-779A-17R-2 (Piece 3, 14-17 cm), 125-
779A-17R-3 (Piece 8b, 77-80 cm), 125-779A-26R-2 (Piece 2b, $50-52 \mathrm{~cm})$ ) are harzburgite (Table 5). The XRD analysis of Group 1 agrees well with the petrographic descriptions of the samples.

Olivine is definitely present in five of the samples and probably present in sample 125-779A-16R-1 (Piece 3, 19-23 cm). This sample is missing the second major peak at $3.88 \AA$ but contains most of the other major and minor peaks. Forsterite is the most common olivine phase present based on the presence of the $5.10 \AA$ (Fo-50) and $3.73 \AA$ (Fo-10) peaks.

Orthopyroxene is a major phase in all the harzburgite samples as well as a minor phase in one of the dunite samples (125-779A-16R-1 (Piece 3, 19-23 cm)). The other dunite (125-779A-19R-2 (Piece 13b, $97-99 \mathrm{~cm})$ ) shows no evidence of orthopyroxene. Bronzite is the most common orthopyroxene phase present. The samples usually have the second major peak of the orthopyroxenes at $3.17 \AA$ but rarely have the third major peak at $3.15 \AA$.

Although clinopyroxene is a relatively minor phase $(\sim 0-2$ modal $\%$ ) in these clasts, it is definitely present in Sample 125-779A-26R-2 (Piece $2 \mathrm{~b}, 50-52 \mathrm{~cm}$ ) and possibly present in the other five samples. Clinoenstatite is the most common clinopyroxene phase present. Usually the major peaks of clinopyroxene at $2.99 \AA$ and $2.94 \AA$ are present, but these peaks also overlap with the forsterite and the bronzite peaks, respectively. Spinel may also be a minor phase present in these samples $(\sim 1$ modal \%).

Serpentine constitutes the bulk of the secondary minerals in these rocks. Lizardite and chrysotile are definitely present in all the samples, based on the diagnostic peaks at 7.27 (for lizardite and chrysotile), $3.89 \AA$ (for lizardite), $1.79 \AA$ (for lizardite), $2.095 \AA$ (for chrysotile), and $1.644 \AA$ (for chrysotile). Antigorite is definitely present in two of the samples (based on the diagnostic peaks at $1.779 \AA, 1.558-1.56 \AA$, and a doublet between 3.53 and $3.66 \AA$ ). Antigorite is definitely absent in Sample 125-779A-17R-3 (Piece $8 \mathrm{~b}, 77-80 \mathrm{~cm}$ ) because although the sample exhibits only one diagnostic peak, its relative intensity is much greater than 2. Brucite is definitely present in all the samples based on the 
Table 3. Major-element (in weight $\%$ oxides) and trace-element (in ppm) data for ultramafic rocks from Hole 779A.

\begin{tabular}{|c|c|c|c|c|c|c|c|c|c|c|c|c|c|}
\hline \multirow[b]{2}{*}{$\begin{array}{l}\text { Core: } \\
\text { Interval } \\
(\mathrm{cm}) \text { : }\end{array}$} & \multicolumn{13}{|c|}{ Dunites } \\
\hline & $\begin{array}{l}\text { 3R-CC } \\
13-15\end{array}$ & $\begin{array}{c}8 R-1 \\
90-93\end{array}$ & $\begin{array}{c}\text { 10R-1 } \\
40-43\end{array}$ & $\begin{array}{c}14 R-1 \\
74-77\end{array}$ & $\begin{array}{c}14 \mathrm{R}-2 \\
21-24\end{array}$ & $\begin{array}{c}15 R-2 \\
24-27\end{array}$ & $\begin{array}{c}16 \mathrm{R}-1 \\
19-23\end{array}$ & $\begin{array}{c}19 \mathrm{R}-2 \\
97-99\end{array}$ & $\begin{array}{c}22 \mathrm{R}-2 \\
18-20\end{array}$ & $\begin{array}{c}22 \mathrm{R}-3 \\
55-57\end{array}$ & $\begin{array}{c}24 \mathrm{R}-1 \\
36-38\end{array}$ & $\begin{array}{c}25 R-1 \\
85-87\end{array}$ & $\begin{array}{l}\text { average } \\
\text { Dunite }\end{array}$ \\
\hline $\mathrm{SiO}_{2}$ & 36.74 & 39.47 & 38.14 & 38.30 & 35.25 & 35.54 & 40.80 & 39.21 & 39.47 & 38.09 & 34.50 & 34.44 & 37.50 \\
\hline $\mathrm{TiO}_{2}$ & 0.00 & 0.00 & 0.00 & 0.00 & 0.00 & 0.00 & 0.00 & 0.00 & 0.00 & 0.00 & 0.00 & 0.00 & 0.00 \\
\hline $\mathrm{Al}_{2} \mathrm{O}_{3}$ & 0.39 & 0.28 & 0.63 & 0.38 & 0.07 & 0.07 & 0.60 & 0.19 & 0.40 & 0.10 & 0.46 & 0.12 & 0.31 \\
\hline $\mathrm{Fe}_{2} \mathrm{O}_{3}$ & 7.38 & 7.63 & 8.08 & 7.33 & 7.14 & 5.66 & 8.05 & 8.15 & 7.36 & 7.76 & 7.31 & 7.02 & 7.41 \\
\hline $\mathrm{MnO}$ & 0.10 & 0.11 & 0.12 & 0.10 & 0.09 & 0.08 & 0.10 & 0.12 & 0.10 & 0.11 & 0.11 & 0.09 & 0.10 \\
\hline $\mathrm{MgO}$ & 40.31 & 41.21 & 41.19 & 41.71 & 41.35 & 42.14 & 43.43 & 44.36 & 40.95 & 42.96 & 38.94 & 43.40 & 41.83 \\
\hline $\mathrm{CaO}$ & 0.14 & 0.15 & 0.60 & 0.44 & 0.10 & 0.21 & 0.54 & 0.25 & 0.15 & 0.13 & 0.37 & 0.20 & 0.27 \\
\hline $\mathrm{Na}_{2} \mathrm{O}$ & 0.00 & 0.00 & 0.00 & 0.00 & 0.00 & 0.00 & 0.00 & 0.00 & 0.00 & 0.00 & 0.00 & 0.00 & 0.00 \\
\hline $\mathrm{K}_{2} \mathrm{O}$ & 0.02 & 0.00 & 0.00 & 0.01 & 0.00 & 0.02 & 0.01 & 0.00 & 0.00 & 0.00 & 4.00 & 0.00 & 0.34 \\
\hline $\mathrm{P}_{2} \mathrm{O}_{5}$ & 0.00 & 0.00 & 0.00 & 0.00 & 0.00 & 0.00 & 0.00 & 0.00 & 0.00 & 0.00 & 0.00 & 0.00 & 0.00 \\
\hline $\mathrm{NiO}$ & 0.28 & 0.28 & 0.30 & 0.31 & 0.30 & 0.45 & 0.32 & 0.32 & 0.27 & 0.30 & 0.29 & 0.34 & 0.31 \\
\hline $\mathrm{Cr}_{2} \mathrm{O}_{3}$ & 0.42 & 0.39 & 0.41 & 0.35 & 0.21 & 0.19 & 0.33 & 0.22 & 0.30 & 0.18 & 0.25 & 0.32 & 0.30 \\
\hline LOI & 14.18 & 9.55 & 9.28 & 9.00 & 14.64 & 16.71 & 4.77 & 6.22 & 9.26 & 9.17 & 16.27 & 12.77 & 10.99 \\
\hline Total & 99.27 & 98.39 & 98.06 & 97.27 & 98.64 & 98.42 & 98.31 & 98.50 & 97.74 & 98.32 & 101.97 & 98.05 & 98.58 \\
\hline Mg\# & 91.54 & 91.45 & 90.99 & 91.85 & 91.98 & 93.65 & 91.45 & 91.51 & 91.68 & 91.65 & 91.35 & 92.45 & 91.80 \\
\hline \% SERP & 80 & 78 & 55 & 70 & 85 & 85 & 17 & 35 & 85 & 60 & 93 & 85 & 69 \\
\hline $\mathrm{Nb}$ & tr & tr & tr & tr & tr & tr & tr & tr & tr & tr & tr & tr & tr \\
\hline $\mathrm{Zr}$ & 1 & 1 & 1 & 0 & 0 & 1 & 1 & 1 & 1 & 1 & 1 & 1 & 1 \\
\hline $\mathrm{Y}$ & nd & 0 & 2 & 1 & nd & nd & 0 & 1 & 1 & 0 & 0 & nd & 0 \\
\hline $\mathrm{Sr}$ & 2 & 2 & 2 & 4 & 0 & 4 & 0 & nd & 1 & 4 & 21 & 3 & 4 \\
\hline $\mathrm{Rb}$ & 1 & 0 & nd & 1 & 0 & 1 & 0 & nd & nd & 1 & nd & 0 & 0 \\
\hline $\mathrm{Zn}$ & 31 & 36 & 35 & 34 & 22 & 33 & 37 & 33 & 31 & 32 & 46 & 33 & 34 \\
\hline $\mathrm{Cu}$ & 1 & 2 & 7 & nd & 1 & nd & 5 & 4 & 2 & 3 & 2 & 3 & 2 \\
\hline $\mathrm{Ni}$ & 2238 & 2208 & 2396 & 2446 & 2398 & 3527 & 2515 & 2520 & 2163 & 2382 & 2667 & 2486 & 2496 \\
\hline $\mathrm{Cr}$ & 2903 & 2650 & 2796 & 2396 & 1144 & 1319 & 2236 & 1509 & 2024 & 1216 & 1688 & 2167 & 2004 \\
\hline v & 25 & 22 & 42 & 22 & 12 & 11 & 32 & 13 & 29 & 8 & 23 & 8 & 21 \\
\hline $\mathrm{Ce}$ & tr & tr & tr & tr & tr & tr & tr & tr & tr & tr & tr & tr & tr \\
\hline $\mathrm{Ba}$ & tr & 13 & tr & tr & tr & nd & 13 & nd & 12 & tr & tr & nd & tr \\
\hline
\end{tabular}

Oxide and elemental abundances are from whole-rock analyses by XRF; $\mathrm{tr}=$ below detection limit $(<5 \mathrm{ppm}$ for NB; $<10 \mathrm{ppm}$ for Ba and Ce $)$; nd $=$ not detected (background count was greater than sample count); LOI = Loss on ignition between $150 \mathrm{deg}$. Ce. and 1030 deg. C.; \% SERP = percentage of serpentinization estimated from thin sections.

presence of the $4.77 \AA$ peak, which is the only main peak not shared with serpentine. Magnetite is possibly present in the samples, but the low modal percentage of this mineral results in a low signal-to-noise ratio for the main peaks. Talc may be a very minor phase, and only Sample 125-779A-16R-1 (Piece 3, 19-23 cm) has the main peak

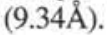

Although magnesite, a common alteration of serpentine in the presence of $\mathrm{CO}_{2}$, was expected, tentative identification could be made in only two samples. In these two, only the $\mathrm{I}_{1}=45$ peak is present. This peak is shared with chrysotile $\left(I / I_{1}=20\right)$ and therefore, the presence of magnesite is suspect. Calcite may be present, but the $3.035 \AA$ $\left(\mathrm{I} / \mathrm{I}_{1}=100\right)$ peak is missing in most of the samples. Aragonite may be present in only one sample. Sample 125-779A-17R-3 (Piece 8b, $77-80 \mathrm{~cm})$ has the second main peak for aragonite $\left(1.98 \AA, \mathrm{I} / \mathrm{I}_{1}=65\right)$ and two minor peaks, but their intensities are too low relative to the second main peak.

The presence of chlorite could not be verified because the $\sim 14.0 \AA$ diagnostic peak of the chlorite group is lacking. The $7.21 \AA$ peak of chlorite is present in most samples of this group but is interfered with by the main serpentine peak $(7.26-7.30 \AA)$. The $4.77 \AA$ peak is also usually present but is also shared by brucite. Therefore, the $\sim 14.0 \AA$ peak is critical for identification. Sample 125-779A-16R-1 (Piece 3, $19-23 \mathrm{~cm}$ ) is thought to contain clinochlore-Ib because it has the first five peaks (including the $14.3 \AA$ peak).

Group 2 has 23 samples of fairly uniform primary mineralogy (Table 6 ), having olivine and orthopyroxene as the dominant primary phases and minor amounts of clinopyroxene and spinel. Forsterite is the dominant olivine phase in all the samples. The orthopyroxene includes enstatite and bronzite. Clinopyroxene phases augite, clinoenstatite, hedenburgite, or diopside are possibly present in many of the samples. Spinel is probably present in most samples but only definitely present in four samples (either spinel, syn-spinel or chromite-Al spinel).

The secondary mineralogy consists predominantly of serpentine. Brucite is present in all of the samples, based on the occurrence of the $4.77 \AA$ peak. Magnetite varies from possibly present to definitely present in all samples, as does talc (although talc is definitely present in Sample 125-780C-8R-1, Piece 10,98-101 cm). Most samples lack magnesite although it is possibly present in four samples. Calcite is possibly present in many samples and probably present in one sample (125-779A-15R-2 (interval 24-27 cm)).

Chlorite group minerals are definitely to possibly present in all samples except Samples 125-779A-25R-1 (interval 85-87 cm) and 125-779A-15R-2 (interval 24-27 cm). The chlorite was identified as either clinochlore-Ib, clinochlore-IIb, or clinochlore-Cr. There is little evidence of any of the clays, except in four samples (125-779A-13R2. Piece $1,50-54 \mathrm{~cm} ; 125-779 \mathrm{~A}-14 \mathrm{R}-1$, Piece $5 \mathrm{a}, 74-77 \mathrm{~cm} ; 125-$ 780C-6R-1, Piece 7a, 61-62 cm; and 125-780C-8R-1, Piece 10, 98-101) where montmorillonite is possibly present (identified by comparison with the pattern for MPDF sample 13-259). Identification of amphibole phases is tentative because their peaks are shared with olivine and orthopyroxene. The required $\sim 8.00 \AA$ peak that indicates the possible presence of an amphibole, usually actinolite, tremolite, hornblende, or magnesiohornblende, was not found. Amphibole may be present in three samples and was tentatively identified as either actinolite or tremolite.

Group 3 is composed of seven of the most altered and metamorphosed $(>90 \%)$ ultramafic samples (Table 7). The peaks indicative of the primary mineralogy are masked by the serpentine and clay peaks; however, olivine, orthopyroxene, and clinopyroxene are possibly to definitely present in these samples. Spinel is possibly to definitely present. 
Table 4. Major element (in weight $\%$ oxides) and trace element (in ppm) data for ultramafic rocks from Hole $780 \mathrm{C}$.

\begin{tabular}{|c|c|c|c|c|c|c|c|}
\hline \multirow[b]{2}{*}{$\begin{array}{c}\text { Core: } \\
\text { Interval }(\mathrm{cm}):\end{array}$} & \multicolumn{6}{|c|}{ Harzburgites } & \multirow{2}{*}{$\begin{array}{c}\text { Dunite } \\
8 \mathrm{R}-1 \\
98-101\end{array}$} \\
\hline & $\begin{array}{c}6 R-1 \\
61-62\end{array}$ & $\begin{array}{l}10 R-1 \\
13-16\end{array}$ & $\begin{array}{c}16 R-1 \\
53-59\end{array}$ & $\begin{array}{c}18 R-1 \\
54-57\end{array}$ & $\begin{array}{c}18 R-1 \\
58-61\end{array}$ & $\begin{array}{l}\text { avg. } \\
\text { harz. }\end{array}$ & \\
\hline $\mathrm{SiO}_{2}$ & 40.70 & 38.42 & 37.76 & 38.56 & 38.85 & 38.86 & 38.43 \\
\hline $\mathrm{TiO}_{2}$ & 0.00 & 0.00 & 0.00 & 0.00 & 0.00 & 0.00 & 0.00 \\
\hline $\mathrm{Al}_{2} \mathrm{O}_{3}$ & 0.47 & 0.60 & 0.54 & 0.63 & 0.66 & 0.58 & 0.65 \\
\hline $\mathrm{Fe}_{2} \mathrm{O}_{3}$ & 7.91 & 7.45 & 7.44 & 7.80 & 7.81 & 7.68 & 7.84 \\
\hline $\mathrm{MnO}$ & 0.11 & 0.11 & 0.11 & 0.11 & 0.11 & 0.11 & 0.11 \\
\hline $\mathrm{MgO}$ & 42.94 & 39.04 & 39.97 & 39.13 & 38.87 & 39.99 & 39.78 \\
\hline $\mathrm{CaO}$ & 0.60 & 0.79 & 0.69 & 0.86 & 0.89 & 0.77 & 0.50 \\
\hline $\mathrm{Na}_{2} \mathrm{O}$ & 0.00 & 0.00 & 0.00 & 0.00 & 0.00 & 0.00 & 0.00 \\
\hline $\mathrm{K}_{2} \mathrm{O}$ & 0.00 & 0.02 & 0.01 & 0.00 & 0.00 & 0.01 & 0.01 \\
\hline $\mathrm{P}_{2} \mathrm{O}_{5}$ & 0.00 & 0.00 & 0.03 & 0.00 & 0.00 & 0.01 & 0.00 \\
\hline $\mathrm{NiO}$ & 0.29 & 0.28 & 0.29 & 0.29 & 0.28 & 0.29 & 0.29 \\
\hline $\mathrm{Cr}_{2} \mathrm{O}_{3}$ & 30.24 & 0.31 & 0.31 & 0.28 & 0.34 & 0.30 & 0.34 \\
\hline LOI & 5.28 & 12.31 & 12.06 & 11.13 & 11.12 & 10.38 & 11.90 \\
\hline Total & 98.55 & 99.31 & 98.60 & 98.78 & 98.92 & 98.83 & 99.84 \\
\hline $\mathrm{Mg} \#$ & 91.49 & 91.21 & 91.41 & 90.86 & 90.79 & 91.16 & 90.95 \\
\hline$\%$ SERP & 65 & 65 & 70 & 75 & 75 & 70 & 55 \\
\hline $\mathrm{Nb}$ & tr & tr & tr & tr & tr & tr & tr \\
\hline $\mathrm{Zr}$ & 0 & 1 & 1 & 1 & 1 & 1 & 1 \\
\hline $\mathrm{Y}$ & nd & 0 & 0 & 1 & 1 & 0 & 0 \\
\hline Sr & 3 & 9 & 11 & nd & 0 & 5 & 6 \\
\hline $\mathrm{Rb}$ & 0 & 1 & 1 & nd & 0 & 0 & 0 \\
\hline $\mathrm{Zn}$ & 33 & 35 & 45 & 33 & 33 & 36 & 32 \\
\hline $\mathrm{Cu}$ & 3 & 2 & 8 & 10 & 12 & 7 & 1 \\
\hline $\mathrm{Ni}$ & 2319 & 2188 & 2264 & 2318 & 2207 & 2259 & 2280 \\
\hline $\mathrm{Cr}$ & 1620 & 2103 & 2126 & 1907 & 2303 & 2012 & 2295 \\
\hline V & 25 & 24 & 30 & 25 & 33 & 27 & 41 \\
\hline $\mathrm{Ce}$ & nd & nd & tr & nd & tr & tr & nd \\
\hline $\mathrm{Ba}$ & tr & $\pi$ & tr & nd & tr & 13 & \\
\hline
\end{tabular}

Oxide and elemental abundances are from whole-rock analyses by XRF; $\mathrm{LOI}=$ loss on ignition between 150 deg. $C$ and 1030 deg. $\mathrm{C}$; $t r=$ below detection limits $(<5 \mathrm{ppm}$ for $\mathrm{Nb} ;<10 \mathrm{ppm}$ for $\mathrm{Ba}$ and $\mathrm{Ce}$ ); $\mathrm{nd}=$ not detected (background count was greater than sample count). \% Serp is estimated from thin section.

Serpentine is the dominant mineral present in the samples. Chrysotile and antigorite are the primary serpentine phases present in greater amounts in the samples of this group. Brucite is probably present in all but three samples $(125-778 \mathrm{~A}-12 \mathrm{R}-2$, interval $43-45 \mathrm{~cm}$; 125-779A-28R-3, Piece 2a, 26-28 cm; and 125-778A-3R-CC, 1-7 cm). Magnetite is possibly to definitely present in all the samples. Talc is probably present in most samples and appears more commonly in this group than in the other groups. Calcite is possibly present in more than half the samples.

The amount of chlorite in each sample is greater than in samples from the other groups. This chlorite varies from clinochlore-Ib, clinochlore-IIb, and clinochlore-Cr. Montmorillonite is possibly present in most samples. Actinolite is present in three samples. Hematite, ilmenite, and coalingite also are much more common in this group. Coalingite is definitely present in Sample 125-779A-8R-1 (Piece 5b, $57-60 \mathrm{~cm})$.

Other secondary minerals present include smectite-kaolinite (MPDF \#29-1490) and chamosite-Ib. Greenalite, from the serpentine mineral group, is also probably present in all the samples. The identification of the secondary mineral peaks is much more uncertain because of the pervasive alteration. Lizardite is more prominent in Groups 1 and 2 and less in Group 3. Antigorite shows the opposite trend and is most prevalent in Group 3.

\section{Observations}

The ultramafic rocks recovered in the holes drilled on Conical Seamount are variably metamorphosed harzburgite and dunite clasts that have undergone subsequent low-temperature alteration. Stratigraphic relationships between the rocks within the holes are difficult to discern; however, it is possible to determine gross variations of the degree of metamorphism and subsequent alteration of the rocks within each hole. The stratigraphic summary of the mineralogy of the ultramafic rocks from these three sites is given in Table 8 .

All the serpentinized harzburgite samples from Site 778 are highly altered and metamorphosed and have nearly uniform composition. The principal stratigraphic variation observed is in the talc and chlorite content of the samples. Toward the bottom of the hole (Cores 125-778A-7 and 125-778A-12, about 49-98 mbsf) XRD analyses show a greater abundance of talc and chlorite. Examinations of fluid compositions and serpentine muds in which the ultramafic clasts are entrained provide strong evidence that water/rock reactions are occurring in situ in the seamount (Fryer, Pearce, Stokking et al., 1990; Fryer and Mottl, this volume). It has been suggested that two components compose the fluids interacting with the rock. One is seawater and one possibly is derived from the subducted Pacific Ocean slab (Fryer and Mottl, this volume).

The probable presence of coalingite $\left[\mathrm{Mg}_{10} \mathrm{Fe} 2\left(\mathrm{CO}_{3}\right)(\mathrm{OH})_{24} \AA 2 \mathrm{H} 2 \mathrm{O}\right]$, in the sample from Core 125-778A-7 supports the suggestion that some of the rocks have interacted with the slab derived pore fluids (Mottl, this volume) associated with the serpentine matrix of the deposits comprising this seamount. The sjogrenite group minerals are prevalent in the serpentine muds analyzed from the flank sites (Fryer and Mottl, this volume). On land, these minerals form in the weathering zone of serpentinite bodies exposed primarily as alteration products of brucite (Mumpton et al., 1965 ) and thus are interpreted to form by the reaction of serpentinized ultramafics with groundwater (fresh water, not seawater) (Fryer and Mottl, this volume).

Mineralogic variations in Hole $779 \mathrm{~A}$ also are subtle. The only striking mineralogical distinction that can be drawn among any group of samples from this hole is the generally greater degree of freshness of the samples in the interval from Cores 125-779A-16 through 125-779A-19 (135-169 mbsf).

Hole $780 \mathrm{C}$ at the summit site contains harzburgite and dunite samples similar to those at Sites 778 and 779, except that they exhibit a generally increasing degree of metamorphism and alteration $(61 \%-$ $69 \%$ ) with depth. The summit holes show evidence for a greater flux of the deep-derived fluid than any of the other holes on Conical Seamount (Mottl, this volume). It is possible the deeper sections of the summit holes reflect more prolonged contact with rising fluids. Rheological studies of the muds from Hole $780 \mathrm{C}$ indicate that the ultramafic rocks can be carried upward with rising silt and clay-sized serpentine muds near the summit (Phipps and Ballotti, this volume).

Table 5. XRD results of group 1 samples ( $<45 \%$ secondary minerals).

\begin{tabular}{|c|c|c|c|c|c|c|c|c|c|c|c|c|c|c|c|c|c|c|c|c|c|c|}
\hline $\begin{array}{l}\text { Sample } \\
\text { site-core }\end{array}$ & interval & $\mathrm{p} \#$ & $\begin{array}{l}\text { rock } \\
\text { name }\end{array}$ & of & opx & cpx & sp & C & L. & A & br & $\mathrm{mt}$ & talc & magn & cal & arag & chl & clay & amph & hem & il & coal \\
\hline $779 A-16 R-1$ & $19-23$ & 3 & D20 & $\emptyset$ & $\varnothing$ & $\emptyset$ & o & O & $\mathrm{O}$ & O & $\mathrm{O}$ & 0 & $\varnothing$ & & 0 & & $\mathrm{O}$ & o & o & o & o & \\
\hline $779 A-16 R-2$ & $74-77$ & 9 & $\mathrm{H} 37$ & $\mathrm{O}$ & $\mathrm{O}$ & $\emptyset$ & o & $\mathrm{O}$ & $\mathrm{O}$ & $\emptyset$ & $\mathrm{O}$ & 0 & $\emptyset$ & & o & & o & 0 & & & & o \\
\hline $779 A-17 R-2$ & $14-17$ & 3 & H36 & $\mathrm{O}$ & $\mathrm{O}$ & $\emptyset$ & & $\mathrm{O}$ & $\mathrm{O}$ & 0 & $\mathrm{O}$ & o & & & o & & o & & & & o & \\
\hline $779 A-17 R-3$ & $77-80$ & $8 b$ & $\mathrm{H} 36$ & $\mathrm{O}$ & $\emptyset$ & $\emptyset$ & o & $\mathrm{O}$ & $\mathrm{O}$ & & $\mathrm{O}$ & o & 0 & & 0 & 0 & o & $\emptyset$ & & & o & \\
\hline $779 A-19 R-2$ & 97-99 & $13 b$ & D38 & $\mathrm{O}$ & & o & 0 & $\mathrm{O}$ & $\mathrm{O}$ & $\mathrm{O}$ & $\mathrm{O}$ & 0 & & & & & 0 & & & & & \\
\hline $779 \mathrm{~A}-26 \mathrm{R}-2$ & $50-52$ & $2 b$ & $\mathrm{H} 36$ & $\mathrm{O}$ & $\emptyset$ & O & 0 & $\mathrm{O}$ & $\mathrm{O}$ & & $\mathrm{O}$ & 0 & & & 0 & & & & & & $\emptyset$ & \\
\hline
\end{tabular}


Table 6. XRD results of group 2 samples (45-89\% secondary minerals).

\begin{tabular}{|c|c|c|c|c|c|c|c|c|c|c|c|c|c|c|c|c|c|c|c|c|c|c|}
\hline $\begin{array}{c}\text { Sample } \\
\text { site-core }\end{array}$ & interval & $\mathrm{p} \#$ & $\begin{array}{l}\text { rock } \\
\text { name }\end{array}$ & ol & opx & cpx & $s p$ & $\mathrm{C}$ & $\mathrm{L}$ & A & br & $\mathrm{mt}$ & talc & magn & cal & arag & chl & clay & amph & hem & il & coal \\
\hline $778 \mathrm{~A}-2 \mathrm{R}-1$ & $89-92$ & 7 & $\mathrm{~S}$ & $\mathrm{O}$ & 0 & $\emptyset$ & o & $\emptyset$ & $\emptyset$ & o & 0 & 0 & 0 & 0 & 0 & $\emptyset$ & 0 & & & $\varnothing$ & & \\
\hline 778A-7R-CC & $7-13$ & & $\mathrm{~S}$ & $\emptyset$ & o & $\emptyset$ & O & & & & $\emptyset$ & $\mathrm{O}$ & $\emptyset$ & $\emptyset$ & o & & $\emptyset$ & 0 & & o & & $\emptyset$ \\
\hline $779 A-3 R-C C$ & $13-15$ & 2 & SD80 & $\mathrm{O}$ & $\mathrm{O}$ & $\varnothing$ & 0 & & 0 & & O & $\emptyset$ & O & & & & $\mathrm{O}$ & o & 0 & o & & \\
\hline $779 A-5 R-2$ & $34-37$ & 3 & SH80 & 0 & $\mathrm{O}$ & o & o & $\emptyset$ & $\mathrm{O}$ & o & O & $\emptyset$ & $\emptyset$ & & & & 0 & o & & o & & \\
\hline $779 \mathrm{~A}-8 \mathrm{R}-1$ & $90-93$ & $8 \mathrm{~b}$ & STD53 & $\mathrm{O}$ & & o & $\mathrm{O}$ & O & o & O & $\mathrm{O}$ & $\emptyset$ & o & & & & $\emptyset$ & & & o & & \\
\hline 779 A-9R-2 & $52-54$ & $4 b$ & STH50 & $\mathrm{O}$ & $\emptyset$ & $\emptyset$ & 0 & $\emptyset$ & o & $\emptyset$ & O & o & $\emptyset$ & & o & & o & & & & & \\
\hline $779 \mathrm{~A}-10 \mathrm{R}-1$ & $40-43$ & 5 & STD56 & $\mathrm{O}$ & & $\emptyset$ & $\emptyset$ & $\emptyset$ & $\emptyset$ & $\emptyset$ & $\mathrm{O}$ & $\mathrm{O}$ & o & & & & $\mathrm{O}$ & & o & & & o \\
\hline $779 \mathrm{~A}-12 \mathrm{R}-1$ & $38-42$ & 6 & SH80 & $\mathrm{O}$ & 0 & $\emptyset$ & $\emptyset$ & $\emptyset$ & $\emptyset$ & 0 & o & $\emptyset$ & $\emptyset$ & & & & 0 & o & & & & \\
\hline $779 A-13 R-2$ & $50-54$ & 1 & SH60 & $\mathrm{O}$ & $\mathrm{O}$ & $\emptyset$ & $\emptyset$ & o & 0 & $\emptyset$ & o & $\emptyset$ & $\emptyset$ & 0 & 0 & 0 & $\mathrm{O}$ & o & $\mathrm{O}$ & $\emptyset$ & & \\
\hline $779 \mathrm{~A}-14 \mathrm{R}-2$ & $21-24$ & 3 & SD76 & O & 0 & & 0 & 0 & 0 & & O & 0 & $\mathrm{O}$ & & & & 0 & & & & & \\
\hline $779 \mathrm{~A}-14 \mathrm{R}-1$ & $74-77$ & $5 a$ & SD57 & O & O & $\emptyset$ & 0 & 0 & O & $\mathrm{O}$ & O & $\emptyset$ & $\emptyset$ & & 0 & & O & o & 0 & & & \\
\hline $779 \mathrm{~A}-14 \mathrm{R}-2$ & $139-141$ & & SH49 & $\mathrm{O}$ & O & O & $\mathrm{O}$ & $\mathrm{O}$ & O & $\mathrm{O}$ & O & $\emptyset$ & $\varnothing$ & & $\emptyset$ & o & $\emptyset$ & & $\emptyset$ & & & \\
\hline $779 A-15 R-2$ & 24-27 & & SD89 & O & 0 & o & 0 & o & $\mathrm{O}$ & o & O & 0 & $\varnothing$ & & & & & & & & & \\
\hline $779 \mathrm{~A}-22 \mathrm{R}-1$ & $63-65$ & 11 & SH52 & o & $\varnothing$ & $\emptyset$ & 0 & o & O & & o & $\varnothing$ & 0 & & & 0 & 0 & & & & & o \\
\hline $779 \mathrm{~A}-22 \mathrm{R}-2$ & $18-20$ & & SD85 & O & 0 & $\mathrm{O}$ & 0 & $\mathrm{O}$ & o & 0 & $\mathrm{O}$ & $\varnothing$ & o & & 0 & & $\emptyset$ & & & o & & $\emptyset$ \\
\hline $779 \mathrm{~A}-22 \mathrm{R}-2$ & $53-57$ & 7 & SD61 & $\mathrm{O}$ & & o & o & $\emptyset$ & $\mathrm{O}$ & 0 & O & o & $\emptyset$ & & 0 & & o & & & & & \\
\hline 779 A-25R-1 & $85-87$ & & SD79 & $\mathrm{O}$ & o & $\emptyset$ & o & $\mathrm{O}$ & $\mathrm{O}$ & & $\mathrm{O}$ & o & $\varnothing$ & & & & & & & & & \\
\hline 779A-26R-3 & $101-103$ & $3 b$ & SH51 & o & $\emptyset$ & $\emptyset$ & $\emptyset$ & $\emptyset$ & O & o & O & o & $\emptyset$ & o & o & 0 & 0 & & & o & & \\
\hline $780 \mathrm{C}-6 \mathrm{R}-1$ & $61-62$ & $7 \mathrm{a}$ & SH63 & $\mathrm{O}$ & $\emptyset$ & $\emptyset$ & $\emptyset$ & O & $\mathrm{O}$ & $\emptyset$ & $\mathrm{O}$ & $\emptyset$ & o & o & o & o & o & o & o & & & \\
\hline $780 \mathrm{C}-8 \mathrm{R}-1$ & $98-101$ & 10 & SD61 & $\mathrm{O}$ & o & $\emptyset$ & 0 & o & $\mathrm{O}$ & o & O & $\emptyset$ & o & & o & & o & o & o & & & \\
\hline $780 \mathrm{C}-10 \mathrm{R}-1$ & $13-16$ & 2 & SH63 & 0 & $\emptyset$ & $\emptyset$ & o & O & 0 & & O & $\emptyset$ & $\emptyset$ & $\emptyset$ & o & o & 0 & & $\emptyset$ & $\mathrm{O}$ & $\emptyset$ & o \\
\hline $780 \mathrm{C}-18 \mathrm{R}-1$ & $54-57$ & $2 a$ & SH69 & 0 & $\emptyset$ & $\mathrm{O}$ & $\emptyset$ & 0 & 0 & 0 & 0 & $\emptyset$ & $\emptyset$ & o & $\emptyset$ & & o & & 0 & & & \\
\hline $780 \mathrm{C}-18 \mathrm{R}-1$ & $58-61$ & $2 \mathrm{a}$ & SH69 & $\mathrm{O}$ & $\emptyset$ & $\varnothing$ & o & o & o & o & O & $\emptyset$ & $\mathrm{O}$ & & 0 & & o & o & 0 & 0 & & \\
\hline
\end{tabular}

$\mathrm{S}=$ serpentinite; $\mathrm{SD}=$ serpentinized dunite; $\mathrm{SH}=$ serpentinized harzburgite; $\mathrm{STD}=$ serpentinized, tectonized dunite; $\mathrm{STH}=$ serpentinized, tectonized harzburgite (numbers after rock name correspond to \% of secondary minerals); ol = olivine; opx = orthopyroxene; $\operatorname{cpx}=$ clinopyroxene; $\mathrm{sp}=\mathrm{spinel} ; \mathrm{C}=$ chrysotile; $\mathrm{L}=$ lizardite; $\mathrm{A}=$ antigorite; $\mathrm{br}=\mathrm{brucite} ; \mathrm{mt}=$ magnetite: magn = magnesite; $c a l=$ calcite; arag = aragonite; chl = chlorite; clay = clay minerals; amph = amphibole; hem = hematite; il = ilmenite; coal = coalingite; $(\mathrm{O}=$ definitely present, $\emptyset$ $=$ probably present, $0=$ possibly present .

Assuming a central conduit for the seamount, Phipps and Ballotti (this volume) suggest that the clasts are either protruded and become part of the flows that blanket the seamount or they may settle back into the conduit during periods of quiescence between eruptions. The ultramafic clasts in the serpentine muds of Conical Seamount represent a depleted supra-subduction zone mantle affected by very lowto medium-grade metamorphism.

The temperature and pressure conditions of the metamorphism represented by the ultramafic rocks from Conical Seamount are complex. On the basis of mineral assemblages and textural relationships it is possible to determine general conditions of metamorphism and history of metamorphic events. A detailed examination of structures and textural relationships (Girardeau and Lagabrielle, this volume) indicates a general retrograde event coincident, Girardeau and Lagabrielle suggest, with the onset of subduction. The thermal history of the Mariana convergent margin as it pertains to this event is discussed by Fryer (this volume). Our observations for this report deal primarily with the mineral assemblages in very low- to moderategrade metamorphism of the rocks studied.

Serpentinization of ultramafic rocks composed mainly of forsterite, $\mathrm{Mg}$-rich pyroxenes and amphiboles depends on the availability of water. Serpentinization occurs in both retrograde or prograde events. It is generally agreed, on the basis of field work, petrographic evidence, and laboratory experiments, that antigorite is stable in the high temperaturepressure range of serpentinization $\left(200^{\circ} \mathrm{C}-600^{\circ} \mathrm{C}\right)$ and chrysotile and lizardite are stable in the lower temperature-pressure range of serpentinization $\left(0^{\circ} \mathrm{C}-200^{\circ} \mathrm{C}\right)$ in prograde events (Coleman, 1971; Moody, 1976; Bonatti et al., 1984). Formation of antigorite requires less water than does that of lizardite or chrysotile because the structure of antigorite accommodates less $\mathrm{Mg}(\mathrm{OH})_{2}$ than does that of either lizardite or chrysotile (Whittaker and Wicks, 1970; Moody, 1976). Therefore, the generally higher temperature characteristic of antigorite formation is attributed by Moody (1976) to the greater degree of dehydration of the host rock and to a lower activity of water as temperatures rise. Solely on the basis of laboratory experiments, the different temperature-pressure stability conditions for chrysotile relative to lizardite cannot be distinguished (Bonatti et al., 1984). Textural relationships between these phases in thin section can elucidate the relative sequence of their formation but still cannot be used to determine temperature-pressure history.

Wenner and Taylor (1971) were able to estimate formation temperatures of serpentine minerals in prograde events in oceanic ultramafic rocks on the basis of ${ }^{18} \mathrm{O} /{ }^{16} \mathrm{O}$ fractionation between coexisting serpentine and magnetite. Approximate equilibrium temperatures are $125^{\circ} \mathrm{C}$ for lizardite, $180^{\circ} \mathrm{C}$ for chrysotile, and $220^{\circ} \mathrm{C}$ to $460^{\circ} \mathrm{C}$ for antigorite (Wenner and Taylor, 1971). The most common serpentine textures in the medium to high temperature range of serpentinization $\left(220^{\circ} \mathrm{C}-600^{\circ} \mathrm{C}\right)$ are antigorite \pm magnetite in interpenetrating configurations that form either through the recrystallization of lizardite \pm chrysotile pseudomorphic textures (formed at lower temperatures), or less frequently through the serpentinization of previously unserpentinized primary minerals (Wicks, 1979). According to Wicks (1979), interpenetrating antigorite textures represent intense metamorphism and form at up to $510^{\circ} \mathrm{C}$ at $2 \mathrm{kbar}$ water pressure. Thus, the reported range of antigorite formation at $2 \mathrm{kbar}$ spans about $220^{\circ} \mathrm{C}$ (Wenner and Taylor, 1971) to $510^{\circ} \mathrm{C}$ (Wicks, 1979). The reported range of chrysotile formation spans about $180^{\circ} \mathrm{C}$ (Wenner and Taylor, 1971) to $440^{\circ} \mathrm{C}$ at $2 \mathrm{kbar}$ (Wicks, 1979). The reported range of lizardite formation spans about $120^{\circ} \mathrm{C}$ (Wenner and Taylor, 1971) to $375^{\circ} \mathrm{C}$ (Wicks, 1979).

According to Wicks (1979), at temperatures below approximately $375^{\circ} \mathrm{C}$ at $2 \mathrm{kbar}$ water pressure, lizardite \pm chrysotile replaces olivine, pyroxene, amphibole, chlorite, and talc. A common mineral assemblage of serpentinization below $375^{\circ} \mathrm{C}$ is lizardite \pm chrysotile \pm magnetite, where lizardite \pm chrysotile form mesh-textured pseudomorphs after olivine and form bastite after pyroxenes and the magnetite is a common byproduct of the serpentinization of the olivine (Wicks, 1979). Lizardite \pm chrysotile has been reported as replacing preexisting antigorite in a lower temperature-pressure regime than is observed for antigorite formation (Coleman, 1971; Mumpton and Thompson, 1975). However, antigorite can persist into a retrograde metamorphic regime (Mumpton and Thompson, 1975). Thus, its presence cannot be used exclusively as an indicator of higher temperatures and pressures of metamorphism. The texture of the common very low grade $\left(120^{\circ} \mathrm{C}-180^{\circ} \mathrm{C}\right)$ serpentinite containing lizardite \pm chrysotile is pseudomorphism of the preexisting primary minerals (Winkler, 1976; Wicks, 1979). Wicks (1979) also notes 
Table 7. XRD results of group 3 samples ( $90 \%$ secondary minerals).

\begin{tabular}{|c|c|c|c|c|c|c|c|c|c|c|c|c|c|c|c|c|c|c|c|c|}
\hline $\begin{array}{l}\text { Sample } \\
\text { site-core }\end{array}$ & interval & $\mathrm{p} \#$ & $\begin{array}{l}\text { rock } \\
\text { name }\end{array}$ & ol & opx & $\operatorname{cpx}$ & $\mathrm{sp}$ & C & L & A & br & $\mathrm{mt}$ & talc & magn & $\mathrm{cal}$ & arag & chl & clay & amph & hem \\
\hline $778 \mathrm{~A}-3 \mathrm{R}-\mathrm{CC}$ & $1-7$ & & $\mathrm{~S}$ & $\mathrm{O}$ & $\varnothing$ & $\mathrm{O}$ & o & o & $\mathrm{O}$ & $\mathrm{O}$ & & $\varnothing$ & o & o & & & o & o & o & \\
\hline $778 \mathrm{~A}-12 \mathrm{R}-2$ & $43-45$ & & SH98 & o & o & $\emptyset$ & o & o & & o & & o & o & o & o & & $\emptyset$ & & o & o \\
\hline $778 \mathrm{~A}-12 \mathrm{R}-2$ & 73-75 & & SH99 & o & o & ø & $\emptyset$ & $\mathrm{o}$ & & $\mathrm{o}$ & o & o & $\varnothing$ & o & o & & 0 & & & o \\
\hline 779A-5R-2 & $40-43$ & 3 & SH96 & $\emptyset$ & $\emptyset$ & $\emptyset$ & $\varnothing$ & o & o & $\mathrm{O}$ & $\varnothing$ & o & $\emptyset$ & & & & o & 0 & & \\
\hline $779 \mathrm{~A}-8 \mathrm{R}-1$ & $57-60$ & $5 \mathrm{~b}$ & SH98 & $\emptyset$ & o & $\emptyset$ & & o & o & o & $\mathrm{O}$ & o & $\emptyset$ & & & & $\emptyset$ & o & & \\
\hline $779 \mathrm{~A}-11 \mathrm{R}-1$ & $14-18$ & 3 & SH97 & $\emptyset$ & o & $\emptyset$ & o & o & o & o & $\emptyset$ & o & $\emptyset$ & & & & & o & & \\
\hline $779 \mathrm{~A}-28 \mathrm{R}-3$ & $26-28$ & $2 \mathrm{a}$ & SH98 & $\mathrm{O}$ & o & $\emptyset$ & o & $\mathrm{O}$ & & $\mathrm{O}$ & & o & $\emptyset$ & o & o & & $\varnothing$ & o & o & \\
\hline
\end{tabular}

$\mathrm{p} \#=$ piece number, where assigned (not all samples were assigned a piece number aboard the ship); $\mathrm{S}=$ serpentinite; $\mathrm{SH}=$ serpentinized harzburgite (numbers after rock name indicate the \% secondary minerals); ol = olivine; opx = orthopyroxene; $\mathrm{cpx}=$ clinopyroxene; $\mathrm{sp}=$ spinel; $\mathrm{C}=$ chrysotile; $\mathrm{L}=$ lizardite; $\mathrm{A}=$ antigorite; $\mathrm{br}=\mathrm{brucite} ; \mathrm{mt}=$ magnetite; magn = magnesite cal = calcite; $\operatorname{arag}=$ aragonite chl = chlorite; clay = clay minerals; amph = amphibole; hem = hematite; il = ilmenite; coal = coalingite; sm-k = smectite-kaolinite kao = kaolinite; gr = greenalite; cron = cronstedite; ch- $\mathrm{lb}=$ chomasite-Ib; $\operatorname{sjog}=$ sjogrenite $(\mathrm{O}=$ definitely present, $\emptyset=$ probably present, $\mathrm{o}=$ possibly present $)$.

Table 8. Variation in mineralogy of ultramafic rocks with depth in Hole 778A, ODP Leg 125.

\begin{tabular}{|c|c|c|c|c|c|c|c|c|c|c|c|c|c|c|c|c|c|c|}
\hline \multirow[b]{2}{*}{$\begin{array}{l}\text { Sample } \\
\text { site-core }\end{array}$} & \multirow[b]{2}{*}{ Interval } & \multirow[b]{2}{*}{$\mathrm{p} \#$} & \multirow[b]{2}{*}{$\begin{array}{l}\text { rock } \\
\text { name }\end{array}$} & \multirow[b]{2}{*}{ alteration } & \multirow[b]{2}{*}{ C } & \multicolumn{4}{|c|}{ Serpentine Grp } & \multicolumn{6}{|c|}{ Layered Grp } & \multirow[b]{2}{*}{ kao } & \multicolumn{2}{|c|}{ Sjog Grp } \\
\hline & & & & & & L & A & G & cron & talc & $\mathrm{br}$ & chl & ch-Ib & clay & $s m-k$ & & coal & sjog \\
\hline $778 \mathrm{~A}-2 \mathrm{R}$ & $89-92$ & 7 & $\mathrm{~S}$ & 4 & $\emptyset$ & $\emptyset$ & o & & & o & o & o & & & & & & \\
\hline $778 \mathrm{~A}-3 \mathrm{R}-\mathrm{CC}$ & $1-7$ & & $\mathrm{~S}$ & 4 & 0 & O & $\mathrm{O}$ & & & o & & o & & 0 & o & 0 & & \\
\hline \multicolumn{19}{|l|}{$778 \mathrm{~A}-4 \mathrm{R}$} \\
\hline \multicolumn{19}{|l|}{$778 \mathrm{~A}-5 \mathrm{R}$} \\
\hline \multicolumn{19}{|l|}{$778 \mathrm{~A}-6 \mathrm{R}$} \\
\hline $778 \mathrm{~A}-7 \mathrm{R}-\mathrm{CC}$ & $7-13$ & & S & 4 & $\mathrm{O}$ & $\varnothing$ & $\mathrm{O}$ & & & $\varnothing$ & $\emptyset$ & $\emptyset$ & & o & & & $\varnothing$ & \\
\hline \multicolumn{19}{|l|}{$778 \mathrm{~A}-8 \mathrm{R}$} \\
\hline \multicolumn{19}{|l|}{$778 \mathrm{~A}-9 \mathrm{R}$} \\
\hline \multicolumn{19}{|l|}{$778 \mathrm{~A}-10 \mathrm{R}$} \\
\hline \multicolumn{19}{|l|}{$778 \mathrm{~A}-11 \mathrm{R}$} \\
\hline $778 \mathrm{~A}-12 \mathrm{R}-2$ & $43-45$ & & SH98 & 4 & $\mathrm{O}$ & & $\mathrm{O}$ & $\emptyset$ & & o & & $\varnothing$ & o & & o & & & \\
\hline $778 \mathrm{~A}-12 \mathrm{R}-2$ & $73-75$ & & SH99 & 4 & $\mathrm{O}$ & & $\mathrm{O}$ & $\emptyset$ & & $\emptyset$ & o & O & o & & o & & & \\
\hline
\end{tabular}

$\mathrm{p} \#$ = piece number, where assigned (not all pieces were assigned a number aboard the ship); $\mathrm{S}=$ serpentinite; $\mathrm{SH}=$ serpentinized harzburgite (numbers after rock name indicate \% secondary minerals); $\mathrm{C}=$ chrysotile; $\mathrm{L}=$ lizardite; $\mathrm{A}=$ antigorite; $\mathrm{G}=$ greenalite; cron = cronstedite; $\mathrm{br}=\mathrm{brucite}$; chl = chlorite; ch- $\mathrm{lb}=$ chamosite-Ib; clay = clay minerals; $\mathrm{sm}-\mathrm{k}=$ smectite-kaolinite $\mathrm{kao}=\mathrm{kaolinite} ; \mathrm{coal}=$ coalingite $;$ sjog = sjogrenite; $\mathrm{cal}=\mathrm{calcite} ;$ arag = aragonite; magn = magnesite; ol = olivine; opx = orthopyroxene; $\operatorname{cpx}=$ clinopyroxene; $\mathrm{sp}=$ spinel; $\mathrm{amph}=$ amphibole; $\mathrm{mt}=$ magnetite; hem = hematite; il = ilmenite; $(\mathrm{O}=$ definitely present, $\emptyset=$ probably present, $\mathrm{o}$ $=$ possibly present) (under alteration, 4 = heavily altered).

that serpentine phases can persist metastably within broad temperature/pressure ranges. Thus, although these criteria (Wicks, 1979) can help determine the grade of metamorphism of the rocks in this study, without further detailed analysis the metamorphic grade of the rocks can only be constrained to very low to medium grade, i.e., $120^{\circ} \mathrm{C}-600^{\circ} \mathrm{C}$.

Brucite is produced by serpentinization with the temperature range of approximately $250^{\circ} \mathrm{C}$ to $450^{\circ} \mathrm{C}$ (Wicks, 1979). The mineral assemblage then becomes lizardite \pm chrysotile \pm brucite \pm antigorite \pm magnetite. Brucite is difficult to determine petrographically because it often assumes a habit as fine grains intimately associated with the lizardite. It is easier to identify in veins. The importance of brucite is that it may define a lower temperature of serpentinization than the presence of antigorite alone or antigorite and chrysotile (Moody, 1976; Wicks, 1979).

There are several different alteration assemblages observed in the rocks examined in this study. Twenty-seven samples (of the 36 samples studied by X-ray diffraction) contain the assemblage chrysotile + lizardite + magnetite + brucite + antigorite. Six samples contain chrysotile + lizardite + magnetite + brucite. Two samples contain the assemblage chrysotile + magnetite + antigorite. One sample contains chrysotile + lizardite + magnetite + antigorite. One sample contains chrysotile + magnetite + antigorite + brucite. One sample contains lizardite + magnetite + brucite. There are only three samples that contain antigorite in the absence of brucite. These samples are all extremely serpentinized ( $>98 \%)$.

Although mineral assemblages alone can be used to determine the range of temperature-pressure conditions in rocks that have under- gone prograde events, it is extremely difficult to use them to determine the range for retrograde events.

Talc is present to some degree in most of the samples analyzed by $\mathrm{X}$-ray diffraction. The occurrence of talc in the same thin sections that have brucite is an apparent contradiction because the stability fields of these two minerals do not overlap. By knowing which of these two mineral phases developed first it would be possible to discuss the history of the rock. However, it is extremely difficult optically to identify the brucite and its interrelationship with talc in thin section. We can say that the rocks are in disequilibrium on a relatively fine (centimeter-size) scale.

The vast majority of thin sections studied demonstrate a pseudomorphic mesh and bastitic texture of lizardite and chrysotile after olivine and orthopyroxene, suggesting recrystallization between $125^{\circ} \mathrm{C}$ and about $500^{\circ} \mathrm{C}$. Rocks containing antigorite indicate formation at a higher temperature between $200^{\circ} \mathrm{C}$ and $600^{\circ} \mathrm{C}$. Modeling of the thermal history of the Mariana forearc (Fryer and Fryer, 1987; Fryer et al., 1989) suggests that a regional reduction in temperature of the outer forearc occurs within the first several hundred thousand years after initiation of subduction. If this modeling is correct, the metamorphism of these rocks would have to be constrained to a very early stage in the evolution of the Mariana subduction system.

Brucite can only be observed petrographically as large cross-cutting veins in both types of the above-mentioned rocks. In almost all rocks analyzed by X-ray diffraction from Sites 779 and 780 (Tables 9 and 10), brucite is definitely present. However, in the samples from Site 778 , brucite is less prevalent, and these generally contain more 
Table 7 (continued).

\begin{tabular}{|c|c|c|c|c|c|c|c|c|}
\hline $\begin{array}{l}\text { Sample } \\
\text { site-core }\end{array}$ & il & coal & sm-k & kao & gr & cron & $\mathrm{ch}-\mathrm{Ib}$ & sjog \\
\hline & & & & $\mathrm{S}$ & $\mathrm{O}$ & $\varnothing$ & o & 0 \\
\hline 778A-3R-CC & & & & SH98S & 0 & 0 & $\emptyset$ & o \\
\hline $778 \mathrm{~A}-12 \mathrm{R}-2$ & o & & & SH99 & 0 & o & $\varnothing$ & $\varnothing$ \\
\hline \multicolumn{9}{|l|}{$778 \mathrm{~A}-12 \mathrm{R}-2$} \\
\hline & & & 3 & SH96 & $\emptyset$ & $\emptyset$ & $\emptyset$ & $\varnothing$ \\
\hline 779A-5R-2 & $\varnothing$ & $\varnothing$ & $5 b$ & SH98 & $\emptyset$ & o & $\emptyset$ & \\
\hline 779A-8R-1 & & $\mathrm{O}$ & 3 & SH97 & $\varnothing$ & o & $\varnothing$ & 0 \\
\hline 779 A-11R-1 & o & & $2 \mathrm{a}$ & SH98 & O & o & $\emptyset$ & o \\
\hline $779 A-28 R-3$ & & & & & & & & \\
\hline
\end{tabular}

fields (Maekawa et al., this volume). Widespread metamorphism of the forearc probably occurred within several hundred thousand years after subduction began (Fryer, this volume). This early event is preserved in the relatively higher temperature/pressure serpentine assemblages noted in the rocks. Subsequent metamorphism occurred in very low to medium-grade conditions of temperature and pressure.

\section{ACKNOWLEDGMENTS}

We are grateful to John Mahoney for his insightful review of this chapter and for suggestions for improvement of the manuscript. We also thank Barbara Jones for her editorial review. The work performed for this study was supported in part by National Science Foundation grant

Table 8 (continued).

\begin{tabular}{|c|c|c|c|c|c|c|c|c|c|c|c|}
\hline \multirow{2}{*}{$\begin{array}{l}\text { Sample } \\
\text { site-core }\end{array}$} & \multirow[b]{2}{*}{ cal } & \multicolumn{3}{|c|}{ Carbonate Grp } & \multicolumn{4}{|c|}{ Others } & \multicolumn{3}{|c|}{ Opaques } \\
\hline & & arag & magn & ol & opx & cpx & sp & amph & $\mathrm{mt}$ & hem & il \\
\hline \multicolumn{12}{|l|}{$778 \mathrm{~A}-1 \mathrm{R}$} \\
\hline $778 \mathrm{~A}-2 \mathrm{R}$ & & $\emptyset$ & 0 & $\mathrm{O}$ & o & $\emptyset$ & o & & 0 & $\emptyset$ & \\
\hline $778 \mathrm{~A}-3 \mathrm{R}-\mathrm{CC}$ & 0 & & o & $\mathrm{O}$ & $\varnothing$ & 0 & 0 & 0 & $\varnothing$ & & \\
\hline \multicolumn{12}{|l|}{$778 \mathrm{~A}-4 \mathrm{R}$} \\
\hline \multicolumn{12}{|l|}{$778 \mathrm{~A}-5 \mathrm{R}$} \\
\hline \multicolumn{12}{|l|}{$778 \mathrm{~A}-6 \mathrm{R}$} \\
\hline 778A-7R-CC & o & & $\emptyset$ & $\emptyset$ & 0 & $\emptyset$ & O & & $\mathrm{O}$ & o & \\
\hline \multicolumn{12}{|l|}{$778 \mathrm{~A}-8 \mathrm{R}$} \\
\hline \multicolumn{12}{|l|}{$778 \mathrm{~A}-9 \mathrm{R}$} \\
\hline \multicolumn{12}{|l|}{$778 \mathrm{~A}-10 \mathrm{R}$} \\
\hline \multicolumn{12}{|l|}{$778 \mathrm{~A}-11 \mathrm{R}$} \\
\hline $778 \mathrm{~A}-12 \mathrm{R}-2$ & 0 & & o & o & o & $\emptyset$ & $\mathrm{O}$ & o & $\mathrm{O}$ & o & o \\
\hline $778 \mathrm{~A}-12 \mathrm{R}-2$ & o & & o & o & o & $\varnothing$ & $\emptyset$ & & $\mathrm{O}$ & o & \\
\hline
\end{tabular}

antigorite. Brucite forms within a temperature range of $250^{\circ} \mathrm{C}$ to $450^{\circ} \mathrm{C}$. Thus, the last metamorphic event must have occurred within the temperature range of brucite formation.

Detailed textural analyses by spectral reflectance, electron microscopy, or microbeam X-ray diffraction are needed in order to further define the intricate mineralogical interrelationships that may indicate the metamorphic history.

\section{SUMMARY}

Several important factors based on these studies and related work have changed concepts of processes active at non-accretionary convergent margins. Evidence suggests that mobilization of the forearc mantle wedge by serpentinization and diapiric intrusion is an important phenomenon in the region between the outer-arc high and the trench. Emplacement of large serpentine seamounts is a common occurrence in the outer half of the Mariana forearc (Fryer et al., 1985; Fryer and Fryer, 1987). One such seamount, Conical Seamount, is composed of unconsolidated serpentine mud flows that have entrained serpentinized ultramafic and metamorphosed mafic rocks. The extent of metamorphism in the samples from this seamount is variable, but all of the ultramafic samples recovered are serpentinized to some degree. Most of the rocks studied from this seamount are harzburgites with very small proportions of clinopyroxene and low contents of alumina. This indicates a depleted mantle rock that represents the residue from a high degree of partial melting or more than one melting event (Ishii et al., this volume).

The nature and magnitude of fluid flow within the forearc at non-accretionary margins are still poorly understood. In the Mariana region, the hydration of the crust and upper mantle of the forearc wedge is probably facilitated by the escape of fluids from the subducting Pacific Plate (Fryer and Fryer, 1987). Large regions beneath the forearc lie within the chlorite, greenschist and blueschist stability
OCE8411717 and by a grant from the U.S. Science Advisory Committee of the Joint Oceanographic Institutions, Inc. This is University of Hawaii SOEST Contribution no. 2604, PG contribution no. 662.

\section{REFERENCES}

Bloomer, S. H., and Hawkins, J. W., 1983. Gabbroic and ultramafic rocks from the Mariana Trench: an island arc ophiolite. In Hayes, D. E. (Ed.), The tectonic and geologic evolution of Southeast Asian seas and islands. Part 2: Washington (Amer. Geophys. Union), Geophys. Monogr. Ser., 27:294-317.

Fryer, P., and Hussong, D. M., 1981. Seafloor spreading in the Mariana Trough: results of Leg 60 drill site selection surveys. In Hussong, D. M., and Uyeda, S. (Eds.), Init. Repts. DSDP, 60: Washington (U.S. Govt. Printing Office), 45-55.

Fryer, P., Ambos, E. L., and Hussong, D. M., 1985. Origin and emplacement of Mariana forearc seamounts. Geology, 13:774-777.

Fryer, P., and Smoot, N. C., 1985. Morphology of ocean plate seamounts in the Mariana and Izu-Bonin subduction zone. Mar. Geol., 64:77-94.

Fryer, P., Haggerty, J., Tilbrook, B., Sedwick, P., Johnson, L. E., Saboda, K. L., Newsom, Y., Karig, D. E., Uyeda, S., and Ishii, T., 1987. Results of Mariana forearc serpentinite diapirism. Eos, 68:1537. (Abstract)

Fryer, P., Saboda, K. L.. Johnson, L. E., Mackay, M. E., Moore, G. F., and Stoffers, P., 1990. Conical Seamount: SeaMarc II, Alvin submersible, and seismic reflection studies. In Fryer, P., Pearce, J., Stokking, L., et al., Proc. ODP Init. Repts., 125: College Station, TX, (Ocean Drilling Program), 69-80.

Fryer, P., and Fryer, G., 1987. Origins of nonvolcanic seamounts in a forearc environment. In Keating, B. H., Fryer, P., Batiza, R., and Boehlert, G. W. (Eds.), Seamounts, islands, and atolls: Washington (Amer. Geophys. Union) Geophys. Monogr. Ser., 43:61-72.

Fryer, P., Pearce, J. A., Stokking, L. B., et al., 1990. Proc. ODP, Init. Repts., 125: College Station, TX (Ocean Drilling Program)

Haggerty, J. A., 1987. Petrology and geochemistry of Neogene sedimentary rocks from the Mariana forearc seamounts. In Keating, B. H., Fryer, P., Batiza, R., and Boehlert, G. W. (Eds.), Seamounts, islands, and atolls: Washington (Amer. Geophys. Union) Geophys. Monogr. Ser., 43:175-186.

Hsui, A. T., and Youngquist, S., 1985. Adynamic model of the curvature of the Mariana Trench. Nature, 318:454-457. 
Table 9. Variation in mineralogy of ultramafic rocks with depth in Hole 779A, ODP Leg 125.

\begin{tabular}{|c|c|c|c|c|c|c|c|c|c|c|c|c|c|c|c|c|c|c|c|c|c|}
\hline \multirow[b]{2}{*}{$\begin{array}{l}\text { Sample } \\
\text { site-core }\end{array}$} & \multirow[b]{2}{*}{ Interval } & \multirow[b]{2}{*}{$\mathrm{p} \#$} & \multirow[b]{2}{*}{$\begin{array}{l}\text { rock } \\
\text { name }\end{array}$} & \multirow[b]{2}{*}{ alt. } & \multirow[b]{2}{*}{$\mathrm{C}$} & \multicolumn{4}{|c|}{ Serpentine Grp } & \multicolumn{7}{|c|}{ Layered Grp } & \multicolumn{2}{|c|}{ Sjog Gip } & \multicolumn{3}{|c|}{ Carbonate Grp } \\
\hline & & & & & & L & A & G & cron & talc & br & chl & $\mathrm{ch}-\mathrm{Ib}$ & clay & $s m-k$ & kao & coal & sjog & cal & arag & magn \\
\hline \multicolumn{22}{|l|}{$779 \mathrm{~A}-\mathrm{IR}$} \\
\hline \multicolumn{22}{|l|}{ 779A-2R } \\
\hline $779 \mathrm{~A}-3 \mathrm{R}-\mathrm{CC}$ & $13-15$ & 2 & SD80 & 3 & & $\mathrm{O}$ & & & & o & O & $\mathrm{O}$ & & o & & & & & & & \\
\hline \multicolumn{22}{|l|}{$779 \mathrm{~A}-4 \mathrm{R}$} \\
\hline 779A-5R-2 & $34-37$ & 3 & SH 80 & 3 & $\emptyset$ & $\mathrm{O}$ & 0 & & & $\emptyset$ & o & 0 & & o & & & & & & & \\
\hline $779 A-5 R-2$ & $40-43$ & 3 & $\mathrm{SH} 96$ & 4 & o & o & o & $\emptyset$ & 0 & $\emptyset$ & $\emptyset$ & 0 & $\emptyset$ & o & 0 & & $\varnothing$ & o & & & \\
\hline \multicolumn{22}{|l|}{$779 A-6 R$} \\
\hline \multicolumn{22}{|l|}{$779 \mathrm{~A}-7 \mathrm{R}$} \\
\hline $779 A-8 R-1$ & $57-60$ & $5 b$ & SH98 & 4 & $\mathrm{O}$ & 0 & 0 & $\emptyset$ & & $\emptyset$ & $\mathrm{O}$ & $\emptyset$ & & 0 & 0 & & o & & & & \\
\hline $779 \mathrm{~A}-8 \mathrm{R}-1$ & $90-93$ & $8 b$ & STD53 & 2 & $\mathrm{O}$ & 0 & $\mathrm{O}$ & & & 0 & O & $\emptyset$ & & & & & & & & & \\
\hline $779 A-9 R-2$ & $52-54$ & $4 b$ & STH50 & 2 & $\emptyset$ & o & $\emptyset$ & & & $\emptyset$ & 0 & 0 & & & & & & & 0 & & \\
\hline $779 A-10 R-1$ & $40-43$ & 5 & STD56 & 2 & $\emptyset$ & $\emptyset$ & $\emptyset$ & & & 0 & $\mathrm{O}$ & $\mathrm{O}$ & & & & & 0 & & & & \\
\hline $779 A-11 R-1$ & $14-18$ & 3 & SH97 & 4 & $\mathrm{O}$ & 0 & $\mathrm{O}$ & $\emptyset$ & & $\emptyset$ & $\emptyset$ & & & 0 & 0 & & & & & & \\
\hline $779 A-12 R-1$ & $38-42$ & 6 & SH80 & 3 & $\emptyset$ & $\emptyset$ & o & & & $\emptyset$ & 0 & o & & 0 & & & & & & & \\
\hline $779 A-13 R-2$ & $50-54$ & 1 & SH60 & 2 & $\mathrm{O}$ & $\mathrm{O}$ & $\emptyset$ & & & $\varnothing$ & O & $\mathrm{O}$ & & 0 & & & & & 0 & o & 0 \\
\hline $779 A-14 R-1$ & $74-77$ & $5 \mathrm{a}$ & SD57 & 2 & $\mathrm{O}$ & O & $\mathrm{O}$ & & & $\emptyset$ & O & $\mathrm{O}$ & & 0 & & & & & 0 & & \\
\hline $779 \mathrm{~A}-14 \mathrm{R}-2$ & $21-24$ & 3 & SD76 & 3 & O & $\mathrm{O}$ & & & & O & $\mathrm{O}$ & 0 & & & & & & & & & \\
\hline $779 A-14 R-2$ & $139-141$ & & SH49 & 2 & $\mathrm{O}$ & $\mathrm{O}$ & $\mathrm{O}$ & & & $\emptyset$ & $\mathrm{O}$ & $\emptyset$ & & & & & & & $\emptyset$ & o & \\
\hline $779 \mathrm{~A}-15 \mathrm{R}-2$ & $24-27$ & & SD89 & 3 & o & $\mathrm{O}$ & 0 & & & $\varnothing$ & $\mathrm{O}$ & & & & & & & & & & \\
\hline $779 A-16 R-1$ & $19-23$ & 3 & D20 & 1 & $\mathrm{O}$ & $\mathrm{O}$ & 0 & & & $\emptyset$ & $\mathrm{O}$ & $\mathrm{O}$ & & 0 & & & & & 0 & & \\
\hline $779 A-16 R-2$ & $74-77$ & 9 & $\mathrm{H} 37$ & 1 & $\mathrm{O}$ & $\mathrm{O}$ & $\emptyset$ & & & $\emptyset$ & $\mathrm{O}$ & 0 & & 0 & & & 0 & & o & & \\
\hline $779 A-17 R-2$ & $14-17$ & 3 & H36 & 1 & $\mathrm{O}$ & 0 & 0 & & & & $\mathrm{O}$ & $o$ & & & & & & & 0 & & \\
\hline $779 A-17 R-3$ & $77-80$ & $8 b$ & H36 & 1 & $\mathrm{O}$ & $\mathrm{O}$ & & & & 0 & $\mathrm{O}$ & 0 & & $\emptyset$ & & & & & o & o & \\
\hline $779 A-19 R-2$ & $97-99$ & $13 b$ & D38 & 1 & O & O & $\mathrm{O}$ & & & & $\mathrm{O}$ & 0 & & & & & & & & & \\
\hline \multicolumn{22}{|l|}{$779 \mathrm{~A}-20 \mathrm{R}$} \\
\hline \multicolumn{22}{|l|}{$779 \mathrm{~A}-21 \mathrm{R}$} \\
\hline $779 \mathrm{~A}-22 \mathrm{R}-1$ & $63-65$ & 11 & SH52 & 2 & $\mathrm{O}$ & $\mathrm{O}$ & & & & 0 & $\mathrm{O}$ & 0 & & & & & 0 & & & o & \\
\hline $779 A-22 R-2$ & $18-20$ & & SD85 & 3 & $\mathrm{O}$ & $\mathrm{O}$ & o & & & 0 & $\mathrm{O}$ & $\emptyset$ & & & & & $\emptyset$ & & o & & \\
\hline $779 A-22 R-2$ & $53-57$ & 7 & SD61 & 2 & $\emptyset$ & O & o & & & $\emptyset$ & $\mathrm{O}$ & 0 & & & & & & & o & & \\
\hline \multicolumn{22}{|l|}{$779 A-23 R$} \\
\hline \multicolumn{22}{|l|}{$779 \mathrm{~A}-24 \mathrm{R}$} \\
\hline $779 \mathrm{~A}-25 \mathrm{R}-1$ & $85-87$ & & SD79 & 3 & $\mathrm{O}$ & $\mathrm{O}$ & & & & $\emptyset$ & $\mathrm{O}$ & & & & & & & & & & \\
\hline $779 \mathrm{~A}-26 \mathrm{R}-2$ & $50-52$ & $2 \mathrm{~b}$ & $\mathrm{H} 36$ & 1 & $\mathrm{O}$ & O & & & & & O & & & & & & & & 0 & & \\
\hline $779 A-26 R-3$ & $10 \mathrm{I}-\mathrm{I} 03$ & $3 b$ & SHSI & 2 & $\emptyset$ & O & o & & & $\emptyset$ & 0 & 0 & & & & & & & o & o & 0 \\
\hline $779 A-27 R$ & & & & & & & & & & & & & & & & & & & & & \\
\hline $779 \mathrm{~A}-28 \mathrm{R}-3$ & $26-28$ & $2 \mathrm{a}$ & SH98 & 4 & 0 & & 0 & $\emptyset$ & 0 & $\emptyset$ & & $\emptyset$ & o & 0 & $\mathrm{O}$ & $\emptyset$ & & & o & & o \\
\hline
\end{tabular}

$\mathrm{p} \#=$ piece number, where assigned (not all rocks were assigned a number aboard the ship): $\mathrm{SD}=$ serpentinized dunite: $\mathrm{SH}=$ serpentinized harzburgite: $\mathrm{STD}=$ serpentinized, tectonized dunite; $\mathrm{STH}=$ serpentinized, tectonized harzburgite: $\mathrm{D}=$ dunite: $\mathrm{H}=$ harzburgite: (numbers after rock name correspond to the $\%$ of secondary minerals): alt $=$ degree of alteration ( $1=$ freshest, 2 = slightly altered. $3=$ moderately altered, $4=$ heavily altered $): C=$ chrysotile: $\mathrm{L}=$ lizardite: $\mathrm{A}=$ antigorite: $\mathrm{G}=$ greenalite: cron $=$ cronstedite: $\mathrm{br}=$ brucite: chl $=$ chlorite: ch- $\mathrm{lb}$

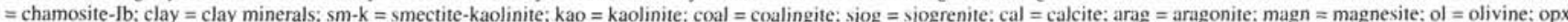
$=$ orthopyroxene $\mathrm{cpx}=$ clinopyroxene: $\mathrm{sp}=$ spinel: $\mathrm{amph}=$ amphibole: $\mathrm{mt}=$ magnetite: hem = hematite: $\mathrm{il}=\mathrm{ilmenite}(\mathrm{O}=$ definitely present. $\emptyset=$ probably present. $\mathrm{o}=$ possibly present $)$.

Table 10. Variation in mineralogy of ultramafic rocks with depth in Hole 780C, ODP Leg 125.

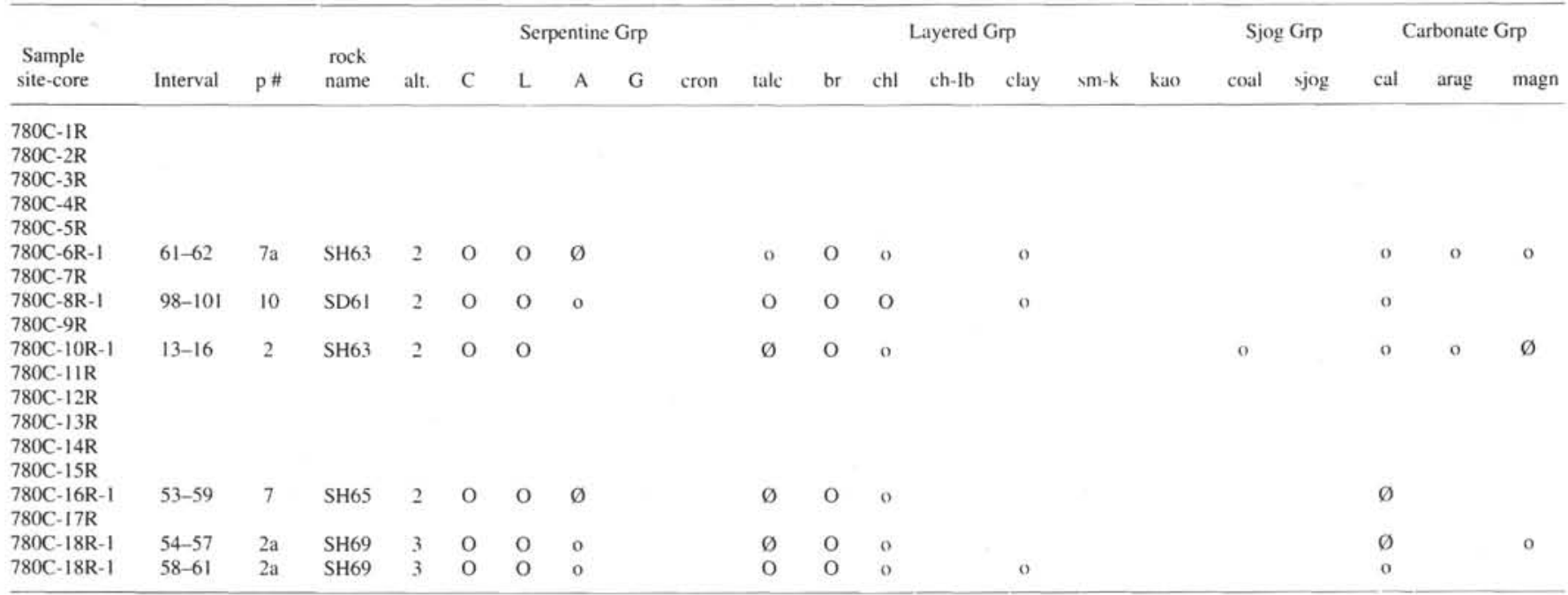

$\mathrm{p} \#=$ piece number. where assigned (not all rocks were assigned a piece number aboard the ship): $\mathrm{SH}=$ serpentinized harzburgite: $\mathrm{SD}=\mathrm{serpentinized} \mathrm{dunite} \mathrm{(numbers} \mathrm{after} \mathrm{rock} \mathrm{name}$ correspond to the $\%$ of secondary minerals $)$ : alt $=$ alteration $(1=$ freshest. $2=$ slightly altered. $3=$ moderately altered. $4=$ heavily altered $): C=$ chrysotile: $\mathrm{L}=$ lizardite: $\mathrm{A}=$ antigorite; $\mathrm{G}=$ greenalite cron = cronstedite: $\mathrm{br}=$ brucite $\mathrm{chl}=$ chlorite: ch-lb = chamosite-lb: clay = clay minerals; $s \mathrm{~m}-\mathrm{k}=\mathrm{smectite}-\mathrm{kaolinite}: \mathrm{kao}=\mathrm{kaolinite} ;$ coal = coalingite:

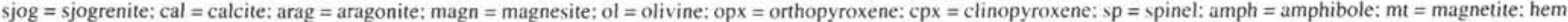
$=$ hematite; $i l=$ ilmenite $(O=$ definitely present. $\emptyset=$ probably present. $0=$ possibly present $)$. 
Table 9 (continued).

\begin{tabular}{|c|c|c|c|c|c|c|c|c|}
\hline \multirow{2}{*}{$\begin{array}{l}\text { Sample } \\
\text { site-core }\end{array}$} & \multicolumn{5}{|c|}{ Others } & \multicolumn{3}{|c|}{ Opaques } \\
\hline & ol & opx & $\mathrm{cpx}$ & $\mathrm{sp}$ & amph & $\mathrm{mt}$ & hem & il \\
\hline \multicolumn{9}{|l|}{$779 A-1 R$} \\
\hline \multicolumn{9}{|l|}{$779 \mathrm{~A}-2 \mathrm{R}$} \\
\hline 779A-3R-CC & $\mathrm{O}$ & $\mathrm{O}$ & $\emptyset$ & o & 0 & $\varnothing$ & o & \\
\hline \multicolumn{9}{|l|}{$779 A-4 R$} \\
\hline 779A-5R-2 & $\mathrm{O}$ & $\mathrm{O}$ & $\mathrm{O}$ & o & & $\emptyset$ & o & \\
\hline $779 A-5 R-2$ & $\emptyset$ & $\emptyset$ & $\emptyset$ & $\emptyset$ & & 0 & & $\varnothing$ \\
\hline \multicolumn{9}{|l|}{ 779A-6R } \\
\hline \multicolumn{9}{|l|}{$779 \mathrm{~A}-7 \mathrm{R}$} \\
\hline $779 \mathrm{~A}-8 \mathrm{R}-1$ & $\emptyset$ & o & $\emptyset$ & & & 0 & & \\
\hline $779 \mathrm{~A}-8 \mathrm{R}-1$ & $\mathrm{O}$ & & 0 & o & & $\emptyset$ & 0 & \\
\hline 779A-9R-2 & $\mathrm{O}$ & $\emptyset$ & $\emptyset$ & 0 & & 0 & & \\
\hline $779 A-10 R-1$ & $\mathrm{O}$ & & $\emptyset$ & $\emptyset$ & 0 & $\mathrm{O}$ & & \\
\hline $779 A-1 \mid R-1$ & $\emptyset$ & o & $\emptyset$ & 0 & & o & & o \\
\hline $779 \mathrm{~A}-12 \mathrm{R}-1$ & $\mathrm{O}$ & $\mathrm{O}$ & $\emptyset$ & $\emptyset$ & & $\emptyset$ & & \\
\hline $779 A-13 R-2$ & $\mathrm{O}$ & o & $\emptyset$ & $\emptyset$ & O & $\emptyset$ & $\emptyset$ & \\
\hline $779 \mathrm{~A}-14 \mathrm{R}-1$ & $\mathrm{O}$ & o & $\emptyset$ & 0 & o & $\emptyset$ & & \\
\hline $779 \mathrm{~A}-14 \mathrm{R}-2$ & $\mathrm{O}$ & o & & o & & 0 & & \\
\hline $779 \mathrm{~A}-14 \mathrm{R}-2$ & $\mathrm{O}$ & o & 0 & O & $\emptyset$ & $\emptyset$ & & \\
\hline $779 A-15 R-2$ & $\mathrm{O}$ & o & 0 & 0 & & 0 & & \\
\hline $779 A-16 R-1$ & $\emptyset$ & $\varnothing$ & $\emptyset$ & o & 0 & 0 & 0 & o \\
\hline $779 A-16 R-2$ & $\mathrm{O}$ & o & $\emptyset$ & o & & 0 & & \\
\hline $779 A-17 R-2$ & $\mathrm{O}$ & o & $\emptyset$ & & & 0 & & o \\
\hline $779 \mathrm{~A}-17 \mathrm{R}-3$ & $\mathrm{O}$ & $\emptyset$ & $\emptyset$ & o & & 0 & & o \\
\hline $779 \mathrm{~A}-19 \mathrm{R}-2$ & $\mathrm{O}$ & & o & 0 & & o & & \\
\hline \multicolumn{9}{|l|}{$779 A-20 R$} \\
\hline \multicolumn{9}{|l|}{$779 \mathrm{~A}-2 \mathrm{IR}$} \\
\hline $779 \mathrm{~A}-22 \mathrm{R}-1$ & $\mathrm{O}$ & $\emptyset$ & $\emptyset$ & $\mathrm{O}$ & & $\emptyset$ & & \\
\hline $779 A-22 R-2$ & O & 0 & $\mathrm{O}$ & 0 & & $\emptyset$ & 0 & \\
\hline $779 A-22 R-2$ & $\mathrm{O}$ & & o & o & & o & & \\
\hline \multicolumn{9}{|l|}{$779 \mathrm{~A}-23 \mathrm{R}$} \\
\hline \multicolumn{9}{|l|}{$779 \mathrm{~A}-24 \mathrm{R}$} \\
\hline $779 A-25 R-1$ & $\mathrm{O}$ & o & $\emptyset$ & o & & 0 & & \\
\hline $779 \mathrm{~A}-26 \mathrm{R}-2$ & $\mathrm{O}$ & $\emptyset$ & $\mathrm{O}$ & o & & o & & $\emptyset$ \\
\hline $779 \mathrm{~A}-26 \mathrm{R}-3$ & $\mathrm{O}$ & $\emptyset$ & $\emptyset$ & $\emptyset$ & & o & 0 & \\
\hline \multicolumn{9}{|l|}{$779 \mathrm{~A}-27 \mathrm{R}$} \\
\hline $779 A-28 R-3$ & $\mathrm{O}$ & o & $\emptyset$ & $\emptyset$ & o & 0 & & \\
\hline
\end{tabular}

Table 10 (continued).

\begin{tabular}{|c|c|c|c|c|c|c|c|c|}
\hline \multirow{2}{*}{$\begin{array}{l}\text { Sample } \\
\text { site-core }\end{array}$} & \multicolumn{5}{|c|}{ Others } & \multicolumn{3}{|c|}{ Opaques } \\
\hline & ol & opx & cpx & sp & amph & $\mathrm{mt}$ & hem & il \\
\hline \multicolumn{9}{|l|}{$780 \mathrm{C}-1 \mathrm{R}$} \\
\hline \multicolumn{9}{|l|}{$780 \mathrm{C}-2 \mathrm{R}$} \\
\hline \multicolumn{9}{|l|}{$780 \mathrm{C}-3 \mathrm{R}$} \\
\hline \multicolumn{9}{|l|}{$780 \mathrm{C}-4 \mathrm{R}$} \\
\hline \multicolumn{9}{|l|}{$780 C-5 R$} \\
\hline $780 C-6 R-1$ & o & $\emptyset$ & $\emptyset$ & $\emptyset$ & 0 & $\emptyset$ & & \\
\hline \multicolumn{9}{|l|}{$780 \mathrm{C}-7 \mathrm{R}$} \\
\hline $780 \mathrm{C}-8 \mathrm{R}-1$ & $\mathrm{O}$ & o & $\emptyset$ & 0 & 0 & $\varnothing$ & & \\
\hline \multicolumn{9}{|l|}{$780 \mathrm{C}-9 \mathrm{R}$} \\
\hline $780 \mathrm{C}-10 \mathrm{R}-1$ & O & $\emptyset$ & $\emptyset$ & 0 & $\varnothing$ & $\emptyset$ & $\mathrm{O}$ & $\emptyset$ \\
\hline \multicolumn{9}{|l|}{$780 \mathrm{C}-11 \mathrm{R}$} \\
\hline \multicolumn{9}{|l|}{$780 \mathrm{C} \cdot 12 \mathrm{R}$} \\
\hline \multicolumn{9}{|l|}{$780 \mathrm{C}-13 \mathrm{R}$} \\
\hline \multicolumn{9}{|l|}{$780 C-14 R$} \\
\hline \multicolumn{9}{|l|}{$780 C-15 R$} \\
\hline $780 \mathrm{C}-16 \mathrm{R}-1$ & $\mathrm{O}$ & $\emptyset$ & $\emptyset$ & O & 0 & $\varnothing$ & & \\
\hline \multicolumn{9}{|l|}{$780 \mathrm{C}-17 \mathrm{R}$} \\
\hline $780 C-18 R-1$ & O & $\varnothing$ & $\mathrm{O}$ & $\emptyset$ & 0 & $\emptyset$ & & \\
\hline $780 \mathrm{C}-18 \mathrm{R}-1$ & O & $\varnothing$ & $\emptyset$ & 0 & 0 & $\varnothing$ & 0 & \\
\hline
\end{tabular}

Hussong, D. M., and Uyeda, S., 1981. Tectonic processes and history of the Mariana arc: a synthesis of the results of Deep Sea Drilling Program Project Leg 60. In Hussong, D. M., and Uyeda, S. (Eds.), Init. Repts. DSDP, 60: Washington (U.S. Govt. Printing Office), 909-929.

Johnson, L. E., and Fryer, P., 1988. Oceanic plate material on the Mariana forearc. Eos, 69:1471. (Abstract)

Johnson, L. E., and Fryer, P., 1990. Petrography, geochemistry and petrogenesis of igneous rocks from the outer Mariana forearc. Earth Planet. Sci. Lett., 100:304-316.

Johnson, L. E., Fryer, P., Taylor, B., Silk, M., and Jones, D. L., 1991. New evidence for crustal accretion in the outer Mariana forearc: Cretaceous radiolarian cherts and MORB-like lavas. Geology.

Karig, D. E., 1971. Structural history of the Mariana island arc system. Geol. Soc. Am. Bull., 83:323-344.

Karig, D. E., and Ranken, B., 1983. Marine geology of the forearc region, southern Mariana island arc. In Hayes, D. E. (Ed.), The tectonic and geologic evolution of Southeast Asian seas and islands. Part 2: Washington (Amer. Geophys. Union), Geophys. Monogr. Ser., 27:266-280.

LaTraille, S. L., and Hussong, D. M., 1980. Crustal structure across the Mariana island arc. In Hayes, D. E. (Ed.), The tectonic and geologic evolution of Southeast Asian seas and islands: Washington (Amer. Geophys. Union), Geophys. Monogr. Ser., 23:209-222.

McCabe, R., and Uyeda, S., 1983. Hypothetical model for the bending of the Mariana arc. In Hayes, D. E. (Ed.), The tectonic and geologic evolution of Southeast Asian seas and islands. Part 2: Washington (Amer. Geophys. Union), Geophys. Monogr. Ser., 27:291-293.

Michael, P. J., and Bonatti, E., 1985. Petrology of ultramafic rocks from Sites 556,558 , and 560, in the North Atlantic. In Bougault, H., and Conde, S. C., et al., Init. Repts. DSDP, 82: Washington (U.S. Govt. Printing Office), 523-528.

Mrosowski, C. L., Hayes, D. E., and Taylor, B., 1982. Multichannel seismic reflection surveys of Leg 60 Sites, Deep Sea Drilling Project. In Hussong, D. M., and Uyeda, S., Init. Repts. DSDP, 60: Washington (U.S. Govt. Printing Office), 57-71.

Saboda, K. L., 1991. Petrology of ultramafic rocks from Conical Seamount based on Alvin Submersible and Ocean Drilling Program studies [M.S. Thesis]. University of Hawaii, Honolulu.

Saboda, K. L., Fryer, P., and Fryer, G., 1987. Preliminary studies of metamorphic rocks collected during Alvin studies of Mariana forearc seamounts. Eos, 68:1534. (Abstract).

Uyeda, S., and Kanamori, H., 1979. Back-arc opening and the mode of subduction. J. Geophys. Res., 84:1049-1061.

Date of initial receipt: 12 September 1991

Date of acceptance: 8 October 1991

Ms 125B-127 